OPEN ACCESS

Edited by: Neta Regev-Rudzki, Weizmann Institute of Science, Israel

Reviewed by: Armando de Menezes Neto, Oswaldo Cruz Foundation (Fiocruz), Brazil

Alicia Rojas,

University of Costa Rica, Costa Rica

${ }^{*}$ Correspondence: Carolina Soekmadi Carolina.Soekmadji@ qimrberghofer.edu.au Grant A. Ramm Grant.Ramm@qimrberghofer.edu.au

Specialty section: This article was submitted to Virus and Host, a section of the journal

Frontiers in Cellular and Infection Microbiology

Received: 27 July 2020 Accepted: 13 October 2020 Published: 10 November 2020

Citation: Lim HK, Jeffrey GP, Ramm GA and Soekmadji C (2020) Pathogenesis of Viral Hepatitis-Induced Chronic Liver Disease: Role of Extracellular Vesicles. Front. Cell. Infect. Microbiol. 10:587628.

doi: 10.3389/fcimb.2020.587628

\section{Pathogenesis of Viral Hepatitis- Induced Chronic Liver Disease: Role of Extracellular Vesicles}

\author{
Hong Kiat Lim ${ }^{1}$, Gary P. Jeffrey ${ }^{2,3}$, Grant A. Ramm ${ }^{1,4^{*}}$ and Carolina Soekmadji ${ }^{1,4 *}$ \\ 1 Hepatic Fibrosis Group, Department of Cellular and Molecular Biology, QIMR Berghofer Medical Research Institute, \\ Brisbane, QLD, Australia, ${ }^{2}$ Faculty of Health and Medical Sciences, University of Western Australia, Perth, WA, Australia, \\ ${ }^{3}$ Sir Charles Gairdner Hospital, Nedlands, Hepatology Department and Liver Transplant Service, Perth, WA, Australia, \\ 4 Faculty of Medicine, The University of Queensland, Brisbane, QLD, Australia
}

Extracellular vesicles are encapsulated lipid nanoparticles secreted by a variety of cell types in living organisms. They are known to carry proteins, metabolites, nucleic acids, and lipids as their cargoes and are important mediators of intercellular communication. The role of extracellular vesicles in chronic liver disease has been reported. Chronic liver disease such as viral hepatitis accounts for a significant mortality and morbidity burden worldwide. Hepatic fibrosis has been commonly associated with the chronic form of viral hepatitis, which results in end-stage liver disease, including cirrhosis, liver failure, and carcinoma in some patients. In this review, we discuss the potential role of extracellular vesicles in mediating communication between infectious agents (hepatitis $B$ and $C$ viruses) and host cells, and how these complex cell-cell interactions may facilitate the development of chronic liver disease. We will further discuss how understanding their biological mechanism of action might be beneficial for developing therapeutic strategies to treat chronic liver disease.

Keywords: extracellular vesicles, chronic liver disease, hepatic fibrosis, therapy, biomarker

\section{INTRODUCTION}

Extracellular vesicles (EV), first described over four decades ago (Chargaff and West, 1946; Wolf, 1967), have now gained recognition as an important mediator of intercellular communication in chronic liver disease (CLD) (Ramakrishnaiah et al., 2013; Hirsova et al., 2016; Devhare et al., 2017; Banales et al., 2019). These membrane-bound nanoparticles are secreted by a variety of cell types in a living organism and are known to carry cargoes such as proteins, metabolites, nucleic acids, and lipids, which mediate complex cell-cell communications. The specific nature of EV-derived cargo has led to an immense interest in using $\mathrm{EV}$ as a tool for disease diagnosis and as a target for therapeutic intervention (Banales et al., 2019; Soekmadji et al., 2020).

The CLD is an umbrella term used for reference to any pathological condition where progressive destruction of liver tissue occurs over 6 months or more. CLD is a significant health concern worldwide; chronic hepatitis $\mathrm{C}$, chronic hepatitis $\mathrm{B}$, alcoholic or non-alcoholic fatty liver disease, and autoimmune hepatitis account for a significant global mortality and morbidity burden. It is estimated that about 844 million people are living with CLD (2017), and at least 2 million deaths per year are associated with CLD globally (Byass, 2014). Cell-cell interactions amongst cell types such as 
liver progenitor cells (LPC), hepatic stellate cells (HSC), and Kupffer cells have been implicated in the development of liver fibrosis and CLD, which eventually progress into an end-stage liver disease including cirrhosis, liver failure and carcinoma (Dwyer et al., 2014; Pozniak et al., 2017). Recently, EVs have been shown to mediate these complex cell interactions among these cell types in the liver, particularly in the context of CLD, which shed light on their potential roles in the development of this disease (Deng et al., 2017).

This review discusses the potential role of EVs in mediating communication between infectious agents and host cells, and how EV-mediated cell-cell interactions facilitate the development of liver disease. We will further discuss how understanding their biological mechanism of action might be beneficial for developing therapeutic strategies to treat chronic liver disease.

\section{LIVER STRUCTURE AND FUNCTION}

The liver is the largest visceral organ in the body, making up an estimated $2-5 \%$ of the adult body weight with roughly $10 \%$ of the body's blood flowing through at any one time (Vekemans and Braet, 2005). The liver performs a myriad of homeostatic roles associated with metabolism, digestion, immunity, and the endocrine system. Microscopically, the liver is composed of two main cell types, parenchymal and non-parenchymal cells (Trefts et al., 2017). Parenchymal cells, including hepatocytes and cholangiocytes, form the majority of cell types in the liver. Hepatocytes, along with the liver sinusoidal endothelial cells (LSEC), line the sinusoids and are the primary epithelial cells of the liver (Trefts et al., 2017). Hepatocytes and LSECs are separated by the perisinusoidal space, also known as space of Dissé. Cholangiocytes line the bile ducts and are involved in the production and modification of bile composition (Figure 1).

In the injured liver, a unique subset of stem-like cells are induced termed hepatic or liver progenitor cells (LPC), also described as oval cells in rodents, which have the potential to reconstitute liver mass by differentiation into hepatocytes or cholangiocytes (Tirnitz-Parker et al., 2010; Köhn-Gaone et al., 2016). LPCs are proposed to originate in the canal of Hering in relatively small numbers at steady state but quickly expand through rapid proliferation following chronic hepatic injury (Dwyer et al., 2014). While their origin remains controversial, recent lineage tracing studies have reported that activated Sox $9^{+}$ductal cells proliferate and differentiate into liver progenitor cells (LPCs) after sustaining chronic hepatic insults (Furuyama et al., 2011).

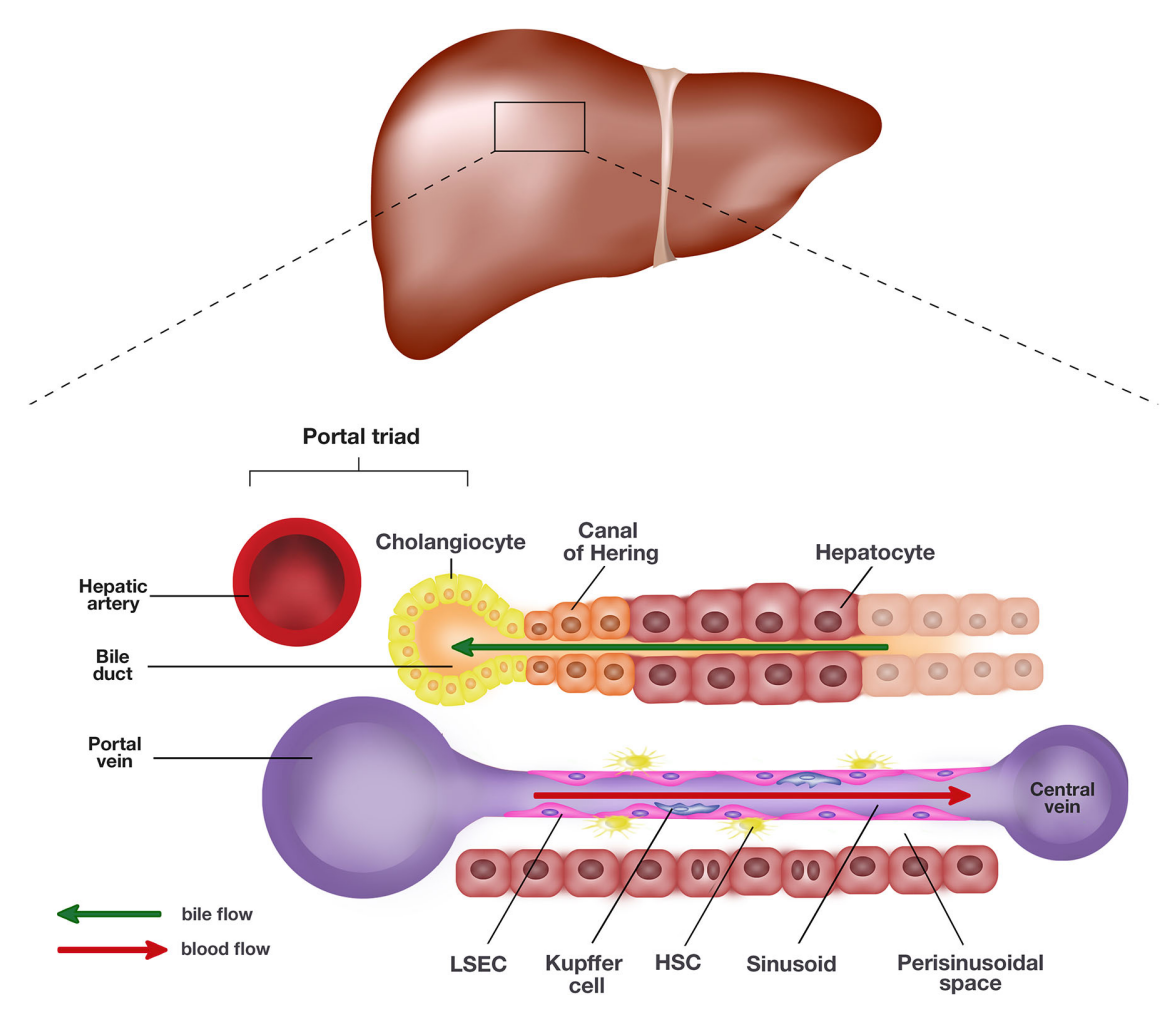

FIGURE 1 Schematic representation of the liver and the single end of its lobule. The portal triad comprising the hepatic artery, bile duct, and portal vein sits at each end of the hepatic lobule. Blood collected from the portal vein and hepatic artery flows toward the central vein through the hepatic sinusoids lined by liver sinusoidal endothelial cells (LSEC) and hepatocytes. The hepatocytes and LSECs are separated by the perisinusoidal space, also known as space of Dissé where hepatic stellate cells (HSC) are located. The hepatocytes produce bile which empties into the bile duct lined by cholangiocytes. The canal of Hering is positioned in the junctional region between cholangiocytes and hepatocytes, where liver progenitor cells (LPC) are proposed to originate. 
Nonparenchymal cells of the liver comprise liver myofibroblast precursors called hepatic stellate cells (HSC), resident liver macrophages or Kupffer cells and LSECs. HSCs which usually reside in the perisinusoidal space are liver-specific mesenchymal cells rich in vitamin A (Higashi et al., 2017). They exist at the ratio of 3.6 to 6 cells per 100 hepatocytes in human liver, and their primary function in the normal liver appears to involve vitamin A storage (Moreira, 2007). Studies have also reported their regulatory role in regulating hepatic blood flow and portal venous pressure at steady state (Geerts, 2001). LSECs are specialized endothelial cells, which form the highly fenestrated sinusoidal endothelium needed for the exchange of fluid, nutrients, and solutes between the sinusoidal blood and hepatocytes (Ni et al., 2017). They are highly endocytic and have a well-developed clathrin-mediated endocytosis system (Simon-Santamaria et al., 2010). Finally, Kupffer cells are specialized macrophages in the liver. They form part of the reticuloendothelial system and are involved in clearing senescent cells and pathogens such as bacteria and viruses. They are one of the key players in hepatic immunity.

\section{PATHOPHYSIOLOGY OF CHRONIC LIVER DISEASE}

While the liver represents an organ with enormous regenerative potential, chronic hepatic insults from pathogens, metabolic insults, and other toxic agents can lead to the development of CLD where the ability of the liver to heal and regenerate diminishes as a consequence of hepatic scarring (fibrosis) and eventually results in deterioration of liver function. The development of CLD is a complex multifactorial process involving many different cell types. Following a hepatic insult, the liver attempts to repair the injured tissue through the normal wound healing process. Paracrine stimulatory signals, including inflammatory mediators, from other cell types such as LPCs, LSECs, Kupffer cells, and hepatocytes within the liver microenvironment activate quiescent dormant HSCs to proliferate and migrate into the primary site of insults. These activated $\alpha$-smooth muscle actin- (SMA) and collagen type Iexpressing HSCs transdifferentiate into myofibroblasts, which produce collagen and extracellular matrix needed for the wound healing process (Higashi et al., 2017). They rapidly lose their ability to store Vitamin A, causing the amount of Vitamin A within the cell to decrease as it divides and distributes Vitamin A-lipid droplets into two daughter cells (Higashi et al., 2005). In CLD, these HSC-derived myofibroblasts contribute to excessive deposition of collagen and extracellular matrix in response to chronic liver injury; thus they are responsible for hepatic fibrosis in a variety of different CLDs in adults including chronic hepatitis $\mathrm{C}$ virus ( $\mathrm{HCV}$ ), alcoholic liver disease, nonalcoholic fatty liver disease (Friedman, 2008), liver cancer (Bridle et al., 2001) haemochromatosis (Ramm et al., 1997), and in pediatric liver disease such as biliary atresia (Ramm et al., 1998) and cystic fibrosis-associated liver disease (Lewindon et al., 2002).
LPCs can rapidly proliferate and differentiate in response to liver injury in a process called the ductular reaction. However, the role of LPCs in liver regeneration and repair seems to be restricted to chronic injury where the replication of mature hepatocytes has been impaired, or the hepatic microenvironment has been substantially changed (Dollé et al., 2010; Best et al., 2013). Clouston et al. showed that inflammatory cytokines such as interferon (IFN) $-\gamma$ inhibited proliferation of hepatocytes, resulting in an expansion of LPCs (Clouston et al., 2005). One possible mechanism for LPC expansion involves tumor necrosis factor-like weak inducer of apoptosis (TWEAK) and its receptor, fibroblast growth factor-inducible 14 (Fn14)-signaling (TWEAK/ Fn14 signaling) (Dwyer et al., 2014). Binding of TWEAK secreted by macrophages or natural killer (NK) cells to Fn14 expressed on the surface of LPCs activates the downstream NFאB signaling pathway, which switches the genes involved in proliferation on, leading to the expansion of LPCs (Tirnitz-Parker et al., 2010; Viebahn et al., 2010; Bird et al., 2013).

Interactions between HSCs and LPCs have been shown to drive hepatic fibrogenesis in CLD. Notch signaling has previously been implicated in the biliary specification of Notch $1 /$ Notch $2^{+}$LPCs through interactions with Jagged $1^{+}$ myofibroblasts (Boulter et al., 2012). The study demonstrated a decrease in expression of biliary genes in LPCs when Notch inhibitor was used in co-cultures of LPCs and HSCs. Interestingly, another study demonstrated impairment in the differentiation of LPCs into cholangiocytes when Notch2 liverspecific knockout mice were treated with 3,5-diethoxycarbonyl1,4-dihydrocollidine (DDC) (Fiorotto et al., 2013). Previous studies in this field identified a novel regulatory mechanism of HSC/LPC crosstalk involving lymphotoxin beta (LT $\beta$ ) and its receptor, LT $\beta R$ (Ruddell et al., 2009; Tirnitz-Parker et al., 2014). LT $\beta$ expression has been shown to increase in several animal models of chronic liver injury (Lowes et al., 2003; Akhurst et al., 2005; Knight et al., 2005; Lee et al., 2005; Dwyer et al., 2014). One study found that $\mathrm{LT} \beta \mathrm{R}^{-/-}$animals fed with choline-deficient, ethionine-supplemented (CDE) diet to induce biliary fibrosis had decreased levels of inflammatory cytokines, which paralleled the reduction in fibrosis and activated HSC numbers, compared to the wild-type animals (Ruddell et al., 2009). Moreover, LPCs were shown to express LT $\beta$, while LT $\beta$ R expression was detected on quiescent/activated HSCs in that study, further suggesting the possible role of LT $\beta / \mathrm{LT} \beta \mathrm{R}$ signaling in HSC/LPC crosstalk (Ruddell et al., 2009).

In CLD, interactions between HSC and LSEC have also been previously reported (Horn et al., 1987; DeLeve et al., 2008b). LSECs undergo phenotypic changes in a process called capillarization prior to HSC activation and fibrosis (Horn et al., 1987; DeLeve et al., 2008b). Activated LSECs defenestrate and form a continuous basement membrane liken to the phenotype of capillaries in order to restrict the movement of toxic molecules which would otherwise be harmful to the liver (Deleve et al., 2008a; Ni et al., 2017). Unfortunately, this safety mechanism also prevents an adequate exchange of solute or fluid between sinusoids and hepatocytes, which further exacerbates the fibrotic process in the liver (Bartneck et al., 2014). While 
healthy LSECs prevent activation of HSC and initiate changes of HSC from an activated to a quiescence state, capillarized LSECs promote HSC activation (Deleve et al., 2008a).

\section{VIRAL HEPATITIS AS A CAUSE OF CHRONIC LIVER DISEASE}

Viral hepatitis is one of the most common causes of CLD affecting close to 397 million individuals worldwide with both hepatitis B virus (HBV) and HCV infection cases combined (Trepo et al., 2014; Westbrook and Dusheiko, 2014; Ferri et al., 2016). There are five main types of hepatitis viruses, including types $\mathrm{A}, \mathrm{B}, \mathrm{C}, \mathrm{D}$, and $\mathrm{E}$, of which, types $\mathrm{B}$ and $\mathrm{C}$ remain prevalent globally, albeit differing in the geographical distribution of disease prevalence. Infections associated with hepatitis types B, $\mathrm{C}, \mathrm{D}$, and $\mathrm{E}$ viruses cause CLD at varying rates with type $\mathrm{E}$ being the rarest, although co-infection of type $B$ is still required for type $\mathrm{D}$ to become chronic. While hepatitis viruses primarily infect hepatocytes, some studies have reported binding of hepatitis types $\mathrm{C}$ viruses to other cell types such as peripheral blood mononuclear cells (PBMC) (El-Awady et al., 2005; Yamada et al., 2005), which raises the possibility that other cell types could play a more significant role in the pathogenesis of viral hepatitis. Most of the pathophysiology of viral-induced CLD is attributed to the exacerbated host immune response to the virus rather than the viral replication in the cells, although more work has to be done to clarify the mechanisms involved (Nakamoto et al., 1998; Buchmann et al., 2013; Ringelhan et al., 2017). This review will focus on $\mathrm{HBV}$ and $\mathrm{HCV}$, given their high degree of clinical relevance in CLD and disease prevalence.

$\mathrm{HBV}$, an enveloped partially double-stranded DNA virus, belongs to the Hepadnaviridae family, genus Orthohepadnavirus (Sekiba et al., 2018). The infectious viral particles are doubleshelled and spherical. They consist of an outer lipid envelope embedded with hepatitis B surface antigens (HBsAg), and a nucleocapsid which comprises hepatitis B core antigens (HBcAg), viral polymerase, and DNA genome (Liang, 2009). The HBV genome is a $3.5 \mathrm{~kb}$ long relaxed circular DNA (rcDNA), consisting of four overlapping reading frames, which encodes envelope proteins, structural core, viral polymerase/reverse transcriptase, and regulatory x protein (HBx) (Liang, 2009). HBV first enters the cells using the sodium taurocholate co-transporting polypeptide receptor (Yan et al., 2012; Ni et al., 2014; Tong and Li, 2014). After entry, the virion un-coats in the cytoplasm, allowing rcDNA to be transported into the host nucleus where rcDNA is converted into covalently closed circular DNA (cccDNA) (Grimm et al., 2011). The host RNA polymerase II transcribes cccDNA into viral messenger RNA (mRNA) transcripts containing viral pregenomic RNA (pgRNA), which are then re-exported back into the cytoplasm of the host cell for translation of viral proteins (Rajbhandari and Chung, 2016). Assembly of nucleocapsids occurs in the cytoplasm where pgRNA is copackaged with viral polymerase/reverse transcriptase for reverse transcription of pgRNA into rcDNA. Mature nucleocapsids are enveloped through the endoplasmic reticulum (ER) and Golgi apparatus before secretion from the host cell via exocytosis (Rajbhandari and Chung, 2016). While the majority of pgRNA is reverse transcribed into rcDNA, a small proportion (10\%) gets synthesized into double-stranded linear DNA (dslDNA) which can integrate into the host genome. However, unlike retroviruses, integration of HBV DNA is not essential for viral replication (Sekiba et al., 2018).

HBV is known to cause both acute and chronic forms of hepatitis. However, it is estimated that $10 \%$ of acute infection progresses to chronic disease (McKeating et al., 2018). The clinical manifestations of acute hepatitis include flu-like symptoms, dark urine, and jaundice, although some cases may appear asymptomatic. While the majority of $\mathrm{HBV}$-infected people recover from the infection completely, some people remain chronically infected with $\mathrm{HBV}$. In chronic hepatitis, a persistent unproductive immune response to $\mathrm{HBV}$ is responsible for substantial necroinflammation of the liver. It has been shown that T helper (Th) 2 type cytokines such as IL-4 and IL-10 are associated with persistent $\mathrm{HBV}$ infections resulting in more severe liver damage (Lee et al., 1999). Indeed, the importance of a protective $\mathrm{T}$ helper (Th) 1 rather than a tolerant Th2 immune response in clearing $\mathrm{HBV}$ has been demonstrated by several studies (Marinos et al., 1995; Maini et al., 2000). Akbar et al. demonstrated the importance of IFN- $\gamma$ in controlling HBV infections by showing a reduction in HBV DNA in the liver and sera after dendritic cells were treated with Th1 type cytokine; IFN- $\gamma$ (Akbar et al., 1996). In addition to host immune response, studies have reported the involvement of viral component $\mathrm{HBx}$ in the progression of chronic HBV. It was first shown by Lee et al. that $\mathrm{HBx}$ antigen was able to inhibit $\mathrm{CD}^{+} \mathrm{T}$ cell response by reducing the production of IFN- $\gamma$ and inducing apoptotic program in $\mathrm{CD}^{+} \mathrm{T}$ cells (Lee et al., 2010). Other findings have also shown that $\mathrm{HBx}$ induces innate pro-inflammatory IL-6, IL8 , and TNF- $\alpha$ but often not at the level sufficient for viral clearance in chronic HBV (Mahé et al., 1991; Lara-Pezzi et al., 1998; Lee et al., 1998). In particular, it has been shown that IL-6 initiates a switch from acute to chronic inflammation by recruiting monocytes to the inflammation sites (Gabay, 2006). Furthermore, $\mathrm{HBx}$ was found to activate and promote the proliferation of HSCs (Martín-Vílchez et al., 2008; Bai et al., 2012).

While it is widely accepted that a substantial number of chronic HBV-associated liver cirrhosis cases develop hepatocellular carcinoma (HCC) as an end-stage complication of the infection (El-Serag and Mason, 1999; Block et al., 2003; ElSerag and Rudolph, 2007), little is known about the process in which the malignant transformation occurs. Persistent hepatic necroinflammation as a result of viral-host immune interaction is, however, recognized as the primary driver of HCC development (Ringelhan et al., 2017; Chen and Tian, 2019). Interestingly, as opposed to HCV-driven HCC, which develops mainly in the presence of cirrhosis, only about $20 \%$ of HCC driven by chronic HBV infection occur with cirrhosis (Chayanupatkul et al., 2017). Indeed, the development of HCC in $\mathrm{HBV}$-infected individuals in the absence of inflammation shed light on alternative mechanisms for tumorigenesis. 
Epidemiology data revealed that $85-90 \%$ of $\mathrm{HBV}$-associated HCCs contained HBV DNA integrated into the host genome (Minami et al., 2005), raising the possibility that the integrated viral DNA might be involved in HCC development. Integration of $\mathrm{HBV}$ viral DNA was previously shown to activate expression of oncogenes such as cyclin E1 (CCNE1), telomerase reverse transcriptase (TERT), and mixed-lineage leukemia 4 (MLL4) (Sung et al., 2012). Moreover, genetic instability leading to chromosomal translocation and accumulation of genetic mutations after integration of viral $\mathrm{HBx}$ into the host genome has been reported (Lee and Rho, 2000; Bonilla Guerrero and Roberts, 2005; Feitelson and Lee, 2007).

$\mathrm{HCV}$ is an enveloped positive-sense single-stranded RNA virus belonging to the Flaviviridae family, genus hepacivirus. The $\mathrm{HCV}$ virions contain E1 and E2 glycoproteins within the viral envelope that surrounded the core protein and nucleocapsid. The $\mathrm{HCV}$ genome is $9.6 \mathrm{~kb}$ long, consisting of two untranslated regions (UTR) 5'-UTR and 3'-UTR and an open reading frame (ORF). The ORF encodes a polyprotein, which is further processed into various viral proteins including core protein, E1, E2, p7, NS2, NS3, NS4A, NS4B, NS5A, and NS5B. The life cycle of HCV, while only partially elucidated, starts with the attachment of HCV to a host receptor. Several host receptors, including lipoprotein (LDL) receptor, scavenger receptor B1 (SR$\mathrm{B} 1$ ), and CD81 tetraspanin (which is also an EV marker) (Théry et al., 2018) have been proposed to be involved. Once bound to its receptor, $\mathrm{HCV}$-receptor complex is internalized through clathrin-mediated endocytosis, releasing the nucleocapsid into the cytoplasm. Viral genomic RNA is freed from the nucleocapsid after uncoating, which then undergoes genomic replication via a negative-sense RNA intermediate and translation of polyproteins at the ER for further posttranslational processing. Assembly and maturation of virion take place in the ER and Golgi apparatus before releasing from the host cell by exocytosis.

About $80 \%$ of acute HCV cases develop into chronic HCV infection due to the inability of the host immune system in clearing the virus (McKeating et al., 2018). Several mechanisms responsible for the persistence of $\mathrm{HCV}$ in the host have been reported. First, the error-prone and high replicating characteristic of HCV RNA polymerase results in a high acquisition of mutations in the viral genome, leading to the generation of many HCV quasispecies with mutated epitopes, which cannot be recognized by cytotoxic $\mathrm{CD} 8^{+} \mathrm{T}$ cells (Irshad et al., 2013). Consequently, the cell-mediated cytotoxic killing of infected host cells is prevented, allowing the viruses to persist (Irshad et al., 2013). Moreover, persistent antigenic stimulation in chronic infection results in $\mathrm{T}$ cell exhaustion, which involves a loss of virus-specific effector $\mathrm{T}$ cells and increased expression of inhibitory molecules such as PD-1 (Penna et al., 2007; Radziewicz et al., 2007). For example, Wedemeyer et al. reported defective IFN- $\gamma$ production and proliferative capacity with $\mathrm{HCV}$-tetramer ${ }^{+} \mathrm{T}$ cells in patients with chronic $\mathrm{HCV}$ infection (Wedemeyer et al., 2002). Second, there is evidence that HCV proteins drive Fas-mediated apoptosis of virus-specific immune cells while promoting infiltration of peripheral $\mathrm{T}$ cells into the liver (Soguero et al., 2002). It is thought that the apoptosis of $\mathrm{T}$ cells in the liver might be partially responsible for liver injury mediated by inflammation (Soguero et al., 2002). Third, it has been reported that HCV E2 glycoprotein suppresses the non-specific cytotoxicity function in NK cells, allowing HCV to persist in affected patients (Crotta et al., 2002). As with HBV infections, persistent hepatic necroinflammation in chronic $\mathrm{HCV}$ infections creates a microenvironment which favors the development of cirrhosis and malignancies. It has been reported that $\mathrm{CD}^{+} \mathrm{T}$ cells and NK cells are directly involved in the pathogenesis of HCV related liver cirrhosis and HCC (Cooper et al., 1999; Karidis et al., 2015; Khatun and Ray, 2019).

\section{THE ROLE OF EXTRACELLULAR VESICLE (S) IN THE PATHOGENESIS OF VIRAL DISEASE}

The extracellular vesicle (EV) is a collective term for "particles released from cells that are delimited by a lipid bilayer and cannot replicate" (Théry et al., 2018). While EVs have been previously categorized into exosomes, microparticles, and apoptotic bodies, what constitutes each subtype has been ambiguous. Since no consensus has been reached on their specific markers, this review will refer to EV subtypes based on the recommendations from the International Society for Extracellular Vesicles (ISEV) (Théry et al., 2018). In terms of size, EVs can be defined as small ( $<100$ or $200 \mathrm{~nm}$ ) and medium/ large (>200nm) EVs (Théry et al., 2018). Small EVs are highly enriched in a class of membrane proteins called tetraspanins such as CD9, CD63, CD81, as well as cytosolic proteins TSG101 and Alix. These proteins also play diverse roles in cell biology and physiology (Andreu and Yáñez-Mó, 2014; Lozano-Andrés et al., 2019). In addition, EVs can be categorized based on their biochemical composition and conditions or cell where they originate (Théry et al., 2018).

Biogenesis of EVs differs among exosomes, microparticles and apoptotic bodies and has been extensively reviewed elsewhere (Akers et al., 2013; Schorey et al., 2015; Abels and Breakefield, 2016; Hirsova et al., 2016). In general, exosomes are described as vesicles that are formed by inward budding at the multivesicular endosomes. Multivesicular endosomes destined for degradation or exocytosis will either fuse with lysosomes for degradation of their contents, or with the plasma membrane for exocytosis (Abels and Breakefield, 2016). Exosome biogenesis involves either endosomal-sorting complex required for transport (ESCRT)-dependent or independent mechanisms. ESCRT is a type of multi-subunit molecular machinery and comprises five complexes (ESCRT-0, I, II, III and VPS4) with specific roles assigned to each ESCRT complex (Hirsova et al., 2016). These complexes are involved in cargo recognition, recruitment, vesicle maturation, and secretion (Hirsova et al., 2016). ESCRT independent mechanism, on the contrary, is largely lipid raft and ceramide-based and was first described in oligodendroglial cells (Trajkovic et al., 2008; Colombo et al., 2014). 


\section{The Potential Role of Extracellular Vesicles in Viral Infectious Disease}

The association between viral particles and EVs is indicated by the presence of viral elements in EVs isolated from infected cells (Table 1). Early studies in human immunodeficiency virus (HIV) have demonstrated the presence of viral transactivating response (TAR) element RNA in EVs isolated by gel filtration Sephadex G-10 spin column and Nanotrap particle A for $\mathrm{CD}^{+}{ }^{+}$ vesicles from sera of HIV-1 infected patients and supernatants of cultured infected J1.1 cells respectively (Table 1) (Narayanan et al., 2013; Sampey et al., 2016). It was shown that these TAR RNA-containing EVs prevented apoptosis and enhanced viral replication in recipient cells, causing these cells to be more susceptible to HIV-1 infection (Narayanan et al., 2013). Their role was further confirmed by a study, which demonstrated decreased susceptibility of recipient cells to HIV-1 infection after the release of those EVs was inhibited (Sampey et al., 2016). Furthermore, HIV virulence factor, Nef detected in plasma EVs of HIV-infected patients using sucrose density gradient ultracentrifugation was shown to correlate with the low $\mathrm{T}$ cell counts in patients (Table 1) (Lee et al., 2016). Indeed, another study reported the induction of $\mathrm{CD} 4^{+} \mathrm{T}$ cell apoptosis in vitro by EV-associated HIV Nef (Table 1) (Lenassi et al., 2010). Like the EVs from HIV-infected cells, the EVs isolated from Epstein-Barr virus (EBV)-positive A-type lymphoblastoid cells contain biomolecules such as latent membrane protein 1 (LMP1) which was found to inhibit NK and T cell functions (Table 1) (Dukers et al., 2000; Flanagan et al., 2003). In the context of human papillomavirus (HPV), it was found that the amount of EVs secreted by HeLa cells increases when E6/E7 oncogene expression is inhibited (Honegger et al., 2013). Moreover, the inhibition of E6/E7 oncogene expression leads to a reduction in the levels of EV cargo survivin, a negative regulator of apoptosis, although the E6/E7 oncogene protein itself has not been detected within the EVs (Honegger et al., 2013). Further studies are needed in part due to the possibility of co-isolation of virus during EV preparation as shown by the presence of retrovirus and xenotropic murine leukemia virus-related virus in isolated EVs using ultracentrifugation (Knouf et al., 2009; Soekmadji et al., 2017). It should be noted that there is an overlap in the mechanism by which viruses and EVs may share in biogenesis, entry, and secretion mechanisms, as shown by enveloped viruses that co-utilize the host's cellular machinery during infection (Nolte-'t Hoen et al., 2016). One cellular mechanism being investigated is the ESCRT which, as mentioned above, forms an integral part of the cellular endosomal system for $\mathrm{EV}$ biogenesis (Abels and Breakefield, 2016). Strickland et al. demonstrated inhibition of $\mathrm{HIV}-1$ replication and budding through depletion of an ESCRT-I protein called TSG101 in the human embryonic kidney, HEK 293 cells (Strickland et al., 2017). TSG101 is also widely utilized as an EV marker (Soekmadji et al., 2013). Interestingly, knocking down TSG101 was shown to increase HBV production in human hepatoma, Huh-7 cells (Stieler and Prange, 2014). They demonstrated the importance of ESCRT-II subunits EAP30, EAP45, and EAP20 for $\mathrm{HBV}$ replication and showed that extracellular $\mathrm{HBV}$ was substantially reduced after knockdown of these ESCRT-II components (Stieler and Prange, 2014). Moreover, several studies have reported a role of tetraspanin EV markers in the life cycle of several viruses such as HIV-1 (Pelchen-Matthews et al., 2003; Fu et al., 2015), HCV (Bartosch et al., 2003; Fénéant et al., 2014), human papillomavirus (HPV) (Spoden et al., 2008; Scheffer et al., 2013), and influenza A virus (IAV) (Earnest et al., 2015; Earnest et al., 2017), which further suggests the potential convergence of $\mathrm{EV}$ and virus biogenesis pathways.

\section{The Role of Extracellular Vesicles in Virus- Associated Chronic Liver Disease}

While it remains unclear to what extent the similarities between viruses and EV biogenesis contributes to the disease progression of viral infections, it is possible that viruses may hijack the mechanism of $\mathrm{EV}$ biogenesis to increase infectivity and

TABLE 1 | Types of viral elements present in extracellular vesicles (EVs) released from cells infected by HIV or Epstein-Barr virus (EBV).

\begin{tabular}{|c|c|c|c|c|c|}
\hline $\begin{array}{l}\text { Causative } \\
\text { agent }\end{array}$ & Cargo & Isolation process & EV characterization & Source & References \\
\hline \multirow[t]{5}{*}{$\mathrm{HIV}^{*}$} & $\begin{array}{l}\text { TAR } \\
\text { element } \\
\text { RNA }\end{array}$ & $\begin{array}{l}\text { Filtration and ultracentrifugation } \\
\text { ExoQuick }^{\text {TM }} \text { reagent and gel filtration } \\
\text { Sephadex G-10 spin column }\end{array}$ & $\begin{array}{l}\text { Western blot (CD63, } \\
\text { CD45, Hsp70\#, and Alix) } \\
\text { Transmission electron } \\
\text { microscopy }\end{array}$ & $\begin{array}{l}\text { Culture supernatant of Jurkat }{ }^{\wedge} \text { and } \mathrm{J} 1.1^{\wedge} \text { cells } \\
\text { Patient sera }\end{array}$ & $\begin{array}{l}\text { (Narayanan } \\
\text { et al., 2013) }\end{array}$ \\
\hline & & $\begin{array}{l}\text { Size-exclusion chromatography and } \\
\text { Nanotrap particle A for } \mathrm{CD} 63^{+} \text {vesicles }\end{array}$ & $\begin{array}{l}\text { Western blot (CD63 and } \\
\text { Hsp70 })\end{array}$ & Culture supernatant of Jurkat ${ }^{\wedge}$ and $\mathrm{J} 1.1^{\wedge}$ cells & $\begin{array}{l}\text { (Sampey } \\
\text { et al., 2016) }\end{array}$ \\
\hline & $\begin{array}{l}\text { Nef } \\
\text { protein }\end{array}$ & Ultracentrifugation & $\begin{array}{l}\text { Western blot (CD9, CD63, } \\
\text { and CD81) }\end{array}$ & $\begin{array}{l}\text { Culture supernatant of plasmid Nef-transfected } \\
\text { HeLa.CIITA^, Jurkat }{ }^{\wedge} \text { and SupT } 1^{\wedge} \text { cells }\end{array}$ & $\begin{array}{l}\text { (Lenassi } \\
\text { et al., 2010) }\end{array}$ \\
\hline & & $\begin{array}{l}\text { Differential centrifugation and column-based } \\
\text { bead isolation }\end{array}$ & $\begin{array}{l}\text { Western blot (CD63 and } \\
\text { CD81) }\end{array}$ & Culture supernatant of monocytes & $\begin{array}{l}\text { (Lee et al., } \\
\text { 2016) }\end{array}$ \\
\hline & & Sucrose density gradient ultracentrifugation & & Patient sera & \\
\hline $\mathrm{EBV}^{*}$ & LMP1 & Sequential centrifugation & $\begin{array}{l}\text { Immunoelectron } \\
\text { microscopy }\end{array}$ & $\begin{array}{l}\text { Culture supernatant of DG- } 75^{\wedge} \text { and QIMR NB- } \\
\text { B95- } 8^{\wedge}\end{array}$ & $\begin{array}{l}\text { (Flanagan } \\
\text { et al., 2003) }\end{array}$ \\
\hline
\end{tabular}

${ }^{*} H I V$, human immunodeficiency virus; EBV, Epstein-Barr virus.

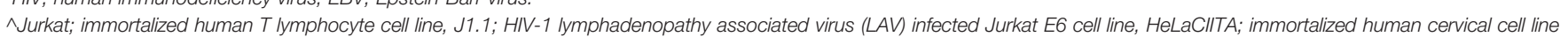

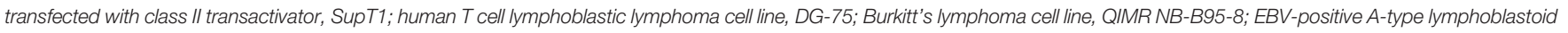
cell line.

${ }^{\#} H$ sp70 is not commonly used as EV markers despite being found in EVs (Théry et al., 2018). 


\begin{tabular}{|c|c|c|c|c|c|c|}
\hline $\begin{array}{l}\text { Causative agent or } \\
\text { disease state }\end{array}$ & $\begin{array}{l}\text { Origin of } \\
\text { cargo }\end{array}$ & Cargo & Isolation process & EV characterization & Source & References \\
\hline \multirow[t]{6}{*}{$\mathrm{HBV}^{*}$} & \multirow[t]{5}{*}{ Viral } & HBV RNA & $\begin{array}{l}\text { Total and CD } 81^{+} \text {exosome isolation kits (Thermo } \\
\text { Fisher Scientific) }\end{array}$ & $\begin{array}{l}\text { Western blot (CD9, CD63, } \\
\text { and CD81) }\end{array}$ & $\begin{array}{l}\text { Culture supernatant of pHBV-transfected } \\
\text { HepG2^ and Huh- } 7^{\wedge} \text { cells }\end{array}$ & (Kouwaki et al., 2016) \\
\hline & & $\begin{array}{l}\mathrm{HBsAg}, \mathrm{HBeAg} \text {, and } \mathrm{HBV} \\
\text { DNA }\end{array}$ & Differential centrifugation & $\begin{array}{l}\text { Flow cytometry (different size } \\
\text { latex beads) }\end{array}$ & Patient platelet-free plasma & (Sukriti et al., 2019) \\
\hline & & $\begin{array}{l}\mathrm{HBV} \text { rcDNA and HBV } \\
\mathrm{RNA}(\mathrm{HBx} \text { and } \mathrm{HBs} / \mathrm{p})\end{array}$ & $\begin{array}{l}\text { Ultracentrifugation and CD63-labeled Dynabeads }{ }^{\circledR} \\
\text { positive selection (Life Technologies) }\end{array}$ & $\begin{array}{l}\text { Flow cytometry (CD81) } \\
\text { Electron microscopy }\end{array}$ & Patient sera & (Yang et al., 2017) \\
\hline & & HBV DNA & Sequential centrifugation and ultracentrifugation & $\begin{array}{l}\text { Immunoprecipitation (CD9, } \\
\text { CD63, and CD81) } \\
\text { Stimulated emission depletion } \\
\text { microscopy (CD81) }\end{array}$ & $\begin{array}{l}\text { Culture supernatant of HBV-infected } \\
\mathrm{PXB}^{\wedge} \text {-cells }\end{array}$ & (Sanada et al., 2016) \\
\hline & & $\begin{array}{l}\mathrm{HBsAg}, \mathrm{HBcAg} \text {, and HBV } \\
\text { DNA }\end{array}$ & Ultracentrifugation and density gradient separation & Western blot (CD9 and CD63) & Culture supernatant of HepAD38^ cells & (Kakizaki et al., 2018) \\
\hline & Host & miR-21 and miR-29a & Total and CD $81^{+}$exosome isolation kits & Western blot (CD63) & $\begin{array}{l}\text { Culture supernatant of pHBV-transfected } \\
\text { HepG2^ cells }\end{array}$ & (Kouwaki et al., 2016) \\
\hline \multirow[t]{3}{*}{$\mathrm{HCV}^{*}$} & Viral & HCV RNA & Sequential centrifugation & $\begin{array}{l}\text { Western blot (CD63 and } \\
\text { CD81) }\end{array}$ & $\begin{array}{l}\text { Culture supernatant of HCV-infected Huh- } \\
7.5 .1 \mathrm{c} 2^{\wedge} \text { hepatocytes }\end{array}$ & (Dreux et al., 2012) \\
\hline & \multirow[t]{2}{*}{ Host } & Galectin-9 & ExoQuick $^{\mathrm{TM}}$ method (System Biosciences) & - & $\begin{array}{l}\text { Culture supernatant of HCV-infected Huh- } \\
7.5 .1^{\wedge} \text { hepatocytes }\end{array}$ & (Harwood et al., 2016) \\
\hline & & miR-19a & $\begin{array}{l}\text { Sequential centrifugation and ExoQuick }{ }^{\mathrm{TM}} \text { method } \\
\text { (System Biosciences) }\end{array}$ & - & $\begin{array}{l}\text { Culture supernatant of HCV-infected } \mathrm{HH}^{\wedge} \\
\text { cells }\end{array}$ & (Devhare et al., 2017) \\
\hline \multirow[t]{4}{*}{$\begin{array}{l}\text { Hepatocellular } \\
\text { Carcinoma }\end{array}$} & \multirow[t]{4}{*}{ Host } & miR-221 and miR-222 & $\begin{array}{l}\text { ExoQuick }{ }^{\mathrm{TM}} \text { Exosome Precipitation Solution } \\
\text { (System Biosciences) }\end{array}$ & $\begin{array}{l}\text { Western blot (CD63, CD9, } \\
\text { and calnexin }{ }^{\#}\end{array}$ & Patient sera & (Sohn et al., 2015) \\
\hline & & miR-21 & Sequential centrifugation and ultracentrifugation & $\begin{array}{l}\text { Western blot (CD63, CD81, } \\
\text { and CD9) } \\
\text { Transmission electron } \\
\text { microscopy }\end{array}$ & 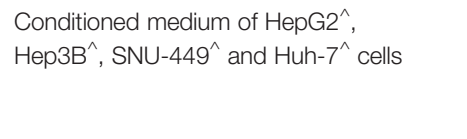 & (Cao et al., 2019) \\
\hline & & & $\begin{array}{l}\text { Filtration and ExoQuick }{ }^{\mathrm{TM}} \text { Exosome Precipitation } \\
\text { Solution (System Biosciences) }\end{array}$ & $\begin{array}{l}\text { Western blot (CD63 and } \\
\text { Tsg101) } \\
\text { Transmission electron } \\
\text { microscopy }\end{array}$ & Patient sera & (Tanaka et al., 2013) \\
\hline & & & Total Exosome Isolation Reagent (Invitrogen) & $\begin{array}{l}\text { Western blot (CD63) } \\
\text { Transmission electron } \\
\text { microscopy }\end{array}$ & Patient sera & (Wang et al., 2014) \\
\hline \multirow[t]{3}{*}{ Hepatic Fibrosis } & \multirow[t]{3}{*}{ Host } & miR-214 & Sequential centrifugation & $\begin{array}{l}\text { Transmission electron } \\
\text { microscopy } \\
\text { Zeta potential analysis and } \\
\text { dynamic light scattering } \\
\text { Western blot (CD9) }\end{array}$ & $\begin{array}{l}\text { Conditioned medium of activated passage } \\
6 \text { mouse } \mathrm{pHSC}^{\wedge}\end{array}$ & (Chen et al., 2014) \\
\hline & & $m i R-199 a-5 p$ & Sequential centrifugation & $\begin{array}{l}\text { NanoSight nanoparticle } \\
\text { tracking analysis } \\
\text { Western blot (CD81) }\end{array}$ & $\begin{array}{l}\text { Conditioned medium of activated passage } \\
6 \text { mouse } \mathrm{pHSC}^{\wedge}\end{array}$ & (Chen et al., 2016) \\
\hline & & $\begin{array}{l}\text { miR-122, miR-192, and } \\
\text { miR-200b }\end{array}$ & $\begin{array}{l}\text { Total Exosome Isolation Reagent (Thermo Fisher } \\
\text { Scientific) }\end{array}$ & $\begin{array}{l}\text { Western blot (CD63 and } \\
\text { Tsg101) }\end{array}$ & Patient plasma & $\begin{array}{l}\text { (Lambrecht et al., } \\
\text { 2017) }\end{array}$ \\
\hline
\end{tabular}

*HBV, hepatitis B virus; HCV, hepatitis C virus.

^HepG2; human hepatocellular carcinoma cell line, Huh-7; human hepatocellular carcinoma cell line, Huh-7.5.1 or Huh-7.5.1c2; subclone of Huh-7 cell line with HCV strain JFH-1 subgenomic replicon, PXB; human primary hepatocytes from liver of humanized mice, HePAD38; HepG2 cell line with a stable integration of an HBV genome, IHH; immortalized human hepatocytes, Hep3B; human hepatocellular carcinoma cell line which contains an integrated HBV genome, SNU-449; human hepatocellular carcinoma cell line which contains an integrated HBV genome, pHSC; primary hepatic stellate cells.

${ }^{\#}$ Calnexin is not commonly used as EV markers despite being found in EVs (Théry et al., 2018). 
transmissibility due to their similarities with EVs. In addition, EVs could be utilized as a modulator of the host immune response against viruses. There is evidence to suggest a potential role of EVs in CLD associated with $\mathrm{HBV}$ and $\mathrm{HCV}$ infections (Table 2; Figure 2). The earliest strong evidence of EV involvement in viral-induced liver disease comes from studies that reported the presence of viral genetic materials co-isolated with EVs from culture supernatant using magnetic beads coated with antibodies specific for an EV marker CD81. Kouwaki et al. found that $\mathrm{CD} 81^{+} \mathrm{EVs}$ containing $\mathrm{HBV}-\mathrm{RNA}$ isolated from plasmid pHBV-transfected HepG2 were able to induce expression of NKG2D ligands on macrophages, which has been known to simulate IFN- $\gamma$ from NK cell (Table 2; Figure 2) (Kouwaki et al., 2016). Interestingly, a similar observation was made with HCV-RNA packaged EVs isolated from the culture supernatant of HCV-infected Huh-7.5.1c2 hepatocytes using sequential centrifugation, where these EVs were shown to activate plasmacytoid dendritic cells which produce type I IFN (Table 2; Figure 2) (Dreux et al., 2012). These observations suggest that EVs may be involved in the innate immune response against the virus. Further, while the contamination of EV preparation from $\mathrm{pHBV}$-transfected HepG2 with free-floating viral genetic materials is possible, the contaminating viral genetic materials are unlikely to have affected the expression of NKG2D ligands on macrophages (Table 2; Figure 2). Although discrimination of virions and free-floating viral genetic materials from EVs has long been a challenging process, purer EV preparations could be obtained by immunoprecipitation using antibodies against EV specific markers (Zhang et al., 2019; Shahjin et al., 2020). As HBV
DNA and proteins were found in EVs isolated using both differential centrifugation (Sukriti et al., 2019) and magnetic beads specific for CD63 (Yang et al., 2017) from the plasma/ serum of patients with chronic HBV infection (Table 2), this strongly suggests that viral cargo could be present in EVs. These EVs containing HBV DNA were taken up by uninfected hepatocytes HepG2, leading to detectable HBV DNA levels (Sukriti et al., 2019) and expression of HBsAg and HBcAg in hepatocytes (Yang et al., 2017), which suggest a potential mechanism for viral transmission (Table 2; Figure 2). Indeed, findings by Sanada et al. demonstrating that HBV DNAcontaining EVs isolated from $\mathrm{HBV}$-infected primary hepatocytes of humanized mice were able to transmit to naïve hepatocytes, paralleled results reported in earlier studies (Table 2; Figure 2) (Sanada et al., 2016). This study also demonstrated the resistance of EVs to antibody neutralization, suggesting the possibility for EVs to act as a physical barrier between the infectious viral particles and the immune system, allowing viruses to establish persistence in chronic patients (Sanada et al., 2016).

Immune modulation in the form of evasion and suppression represent a fundamental process whereby viruses establish persistent infection (Figure 2). Indeed, viruses have been able to co-evolve with their hosts successfully for centuries as obligate intracellular parasites using various immune evasion and suppression strategies. However, utilization of EVs as a mechanism for immune modulation by viruses is a relatively new concept put forward by various groups. It has been shown that EVs isolated using immunomagnetic separation from patients with chronic $\mathrm{HBV}$ infection were able to inhibit NK

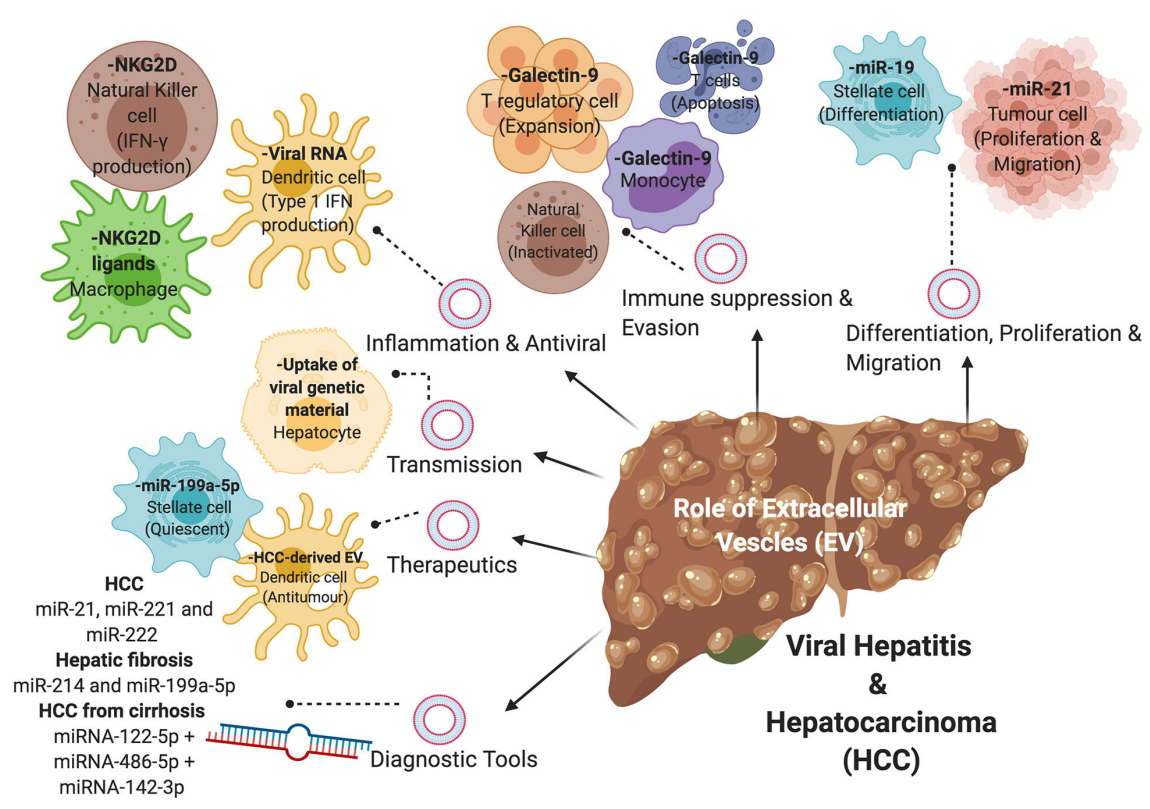

FIGURE 2 | The role of extracellular vesicles (EVs) in viral-associated liver disease. EVs containing nucleic acids, proteins, or metabolites are involved in the disease progression of viral hepatitis and HCC via various mechanisms, including differentiation of hepatic stellate cells, proliferation and migration of tumor cells, immune suppression and evasion, inflammation and antiviral properties, and transmission of virions. EVs can also be used in the diagnosis and treatment of viral-associated liver disease. 
cell functions (Table 2) (Yang et al., 2017). Interestingly, these EVs were also able to transfer HBV rcDNA and HBV RNA (HBx and $\mathrm{HBs} / \mathrm{p}$ ) into NK cells from healthy donors when co-cultured (Yang et al., 2017). A similar finding was reported with HCV, where HCV-containing EVs from Huh-7.5.1 hepatocytes infected with HCV were able to induce expression of galectin-9 on monocytes (Table 2; Figure 2) (Harwood et al., 2016). Galectin-9 was previously found to be upregulated on Kupffer cells in livers of HCV-infected patients, which coincides with an elevated level of galectin-9 in chronic HCV patients. It was reported that galectin- 9 promotes the expansion of Foxp $3^{+}$ regulatory $\mathrm{T}$ cells (Tregs) and apoptosis of HCV-specific $\mathrm{T}$ cells (Mengshol et al., 2010), resulting in immunosuppression.

EVs harvested from HepAD38 expressing HBV pgRNA (using density gradient centrifugation) were able to immunosuppress monocytes by upregulating expression of programmed death-ligand-1 (PD-L1) (Kakizaki et al., 2018). PD-L1 is known to bind to PD-1 expressed on T cells and inhibits $\mathrm{T}$ cell activation and proliferation, which was evidenced by a decrease in expression of an early marker of lymphocyte activation, CD69 in that study (Kakizaki et al., 2018). Furthermore, microRNAs (miRNAs) associated with EVs have been implicated in the modulation of the host immune response by HBV. In particular, EV-associated miR-21 and miR-29a, which were isolated from pHBV-transfected HepG2 cells, downregulate IL-12 production and depress the immune response to HBV (Table 2) (Kouwaki et al., 2016). IL-12 is a known key regulator for Th1 differentiation and NK cell activation (Scharton-Kersten et al., 1995). Importantly, IL-12 also stimulates IFN- $\gamma$ secretion from activated T and NK cells (Gately et al., 1998). The expression of miR-21 in the context of HCC development has also been shown to positively correlate with HCC progression (Table 2). Cao et al. found that EVassociated miR-21 positively regulates proliferation and migration of HCC cells, resulting in tumor growth and metastasis (Cao et al., 2019). In another study, Liu et al. has shown that EV-associated miR-92a-2-5p isolated from THP-1 macrophages were able to increase liver cancer cell invasion by decreasing the expression of androgen receptors on cancer cells (Liu et al., 2020). It is noteworthy that the role of EV-associated miRNA in disease progression is, however, not restricted to immune cells in CLD. EVs derived from HCV-infected hepatocytes were reported to contain miR-19a that activated HSCs for differentiation into myofibroblasts (Devhare et al., 2017). It was found that miR-19a was highly upregulated in the sera of chronic HCV patients (Devhare et al., 2017).

Taken together, we propose that viruses move from the acute phase of infection to the chronic phase of infection by virtue of their biology, immune evasion mechanisms, and modulation of the host immune response. While the initial innate immune response provides the first line of defense against invading viruses such as $\mathrm{HBV}$ and $\mathrm{HCV}$, its ability for viral clearance is limited (Szabo and Dolganiuc, 2008; Tang et al., 2018). As such, it is possible that EVs act as a sanctuary for viral components of $\mathrm{HBV}$ and HCV during the acute phase of infection where it would be difficult for virus-specific antibodies or immune cells to have access to them (Sanada et al., 2016). This provides the viruses with an excellent mode of transmission to uninfected cells, allowing viral persistence to be established (Yang et al., 2017), while the immune system continuously attempts to eliminate the viruses without any success. Persistent unproductive immune response results in an inflammatory microenvironment within the liver that is favorable for the development of liver fibrosis, cirrhosis, and HCC transformation (Ringelhan et al., 2017; Chen and Tian, 2019). Indeed, it would be interesting to test whether blocking the $\mathrm{EV}$ biogenesis pathway would decrease the risk for the development of liver cirrhosis and HCC since studies in cell culture systems have already shown that HCV titer is lowered when the release of EVs is blocked (Ramakrishnaiah et al., 2013; Shrivastava et al., 2013). To this end, it is important to emphasize that the current understanding of the role of EVs in viralassociated liver disease is incomplete and more research is required to bridge knowledge gaps.

\section{The Role of Extracellular Vesicles as a Biomarker for Virus-Associated Chronic Liver Disease}

EVs from blood and urine may be used as a potential noninvasive diagnostic tool for early detection of viral-associated CLD and HCC, which remain challenging to diagnose in part because most patients remain asymptomatic in early stages of disease pathogenesis. Of note, a large proportion $(55-85 \%)$ of $\mathrm{HCV}$ patients have been reported to develop chronic hepatitis from the initial acute phase of the infection (Ringelhan et al., 2017). It is estimated that $20-30 \%$ of chronic HCV patients develop liver cirrhosis 15-25 years after infection (Lingala and Ghany, 2015) and $67-91 \%$ of these patients die from liverassociated causes such as HCC and liver failure if they do not receive timely antiviral therapy (Fattovich et al., 2002; Kobayashi et al., 2006; Toshikuni et al., 2009). Furthermore, poor prognosis of HCC is often associated with a late diagnosis of the disease. The 5 -year survival rate for HCC is $12 \%$, with a median survival of an estimated 6 to 20 months following diagnosis (McGlynn and London, 2011; McGlynn et al., 2015; Golabi et al., 2017). The 5 -year survival rate increases to $>70 \%$ for patients if the diagnosis is made at an early stage (Tsuchiya et al., 2015).

HBV infection is currently detected via a serological assay for viral antigen, followed by a confirmatory real-time PCR test for viral DNA (Krajden et al., 2005; WHO, 2017). HCV is detected via a serological assay for viral antibody followed by confirmatory real-time PCR for RNA (Krajden et al., 2005; WHO, 2017). Subsequent staging of liver disease upon confirmation of viral infection involves assessment for clinical features of advanced liver disease/cirrhosis and non-invasive tests such as aspartate aminotransferase (AST)-to-platelet ratio index (APRI) and transient elastography (FibroScan) (WHO, 2017). However, clinical assessment, APRI and transient elastography have inherent limitations and failure rates; for instance, APRI is not liver-specific and does not discriminate intermediate fibrosis stages well, while transient elastography may have high failure rates and false positive results due to obesity, non-fasting state, acute hepatitis and inflammation, and inexperienced operators (Patel and Sebastiani, 2020). 
In terms of diagnosis of HCC, it is unique cancer in that the diagnosis can be made solely on the basis of specific imaging characteristics of liver lesions using computer tomography imaging or magnetic resonance imaging without the need for liver biopsy (Cartier and Aubé, 2014). However, a definitive diagnosis of HCC in a non-cirrhosis disease background may still require an invasive liver biopsy. While liver biopsy remains the reference standard for the diagnosis of HCC, it is a costly procedure that only allows a small part of the liver to be examined and interpreted (Sumida et al., 2014; Sung et al., 2018). This increases the chance of sampling errors in heterogeneous solid liver tumor (Sung et al., 2018). Moreover, this procedure is associated with known morbidities, such as pain and complications. Therefore, it has been reserved for more complicated cases of HCC which cannot be definitively diagnosed using non-invasive imaging methods (Cartier and Aubé, 2014).

To circumvent the limitations associated with the current diagnostic regime for early detection of viral-associated CLD and HCC, various different types of "liquid biopsy" have been proposed as a potential diagnostic tool by several groups (Weis et al., 2019; Jeffrey et al., 2020). Liquid biopsies may contain various different combinations of analytes, circulating tumor cells, cell-free tumor DNA, mRNA, miRNAs, proteins, or metabolites (Mattox et al., 2019), as demonstrated for the diagnosis of HBVderived HCC by Qu et al. (2019; Jeffrey et al., 2020). Weis and colleagues recently proposed in a pilot study the use of a serum miRNA panel comprising miR-122-5p, miR-486-5p, and miR142-3p to discriminate HCV-derived HCC from mild disease and cirrhosis (sensitivity of $80 \%$, a specificity of $95 \%$, the negative predictive value of $82 \%$, the positive predictive value of $74 \%$, and overall accuracy of 78\%) (Weis et al., 2019), although these miRNAs were not identified as EV-associated. More recently, there has been a growing interest in EVs as biomarkers for viral-associated CLD and HCC. An EV-based liquid biopsy is useful because EVs from diseased individuals often carry specific proteins, nucleic acids, and metabolites that can reveal the status of disease (Whiteside, 2017; Hoshino et al., 2020). Unlike standard liver biopsy, liquid biopsy is non-invasive and less costly to perform. Furthermore, as EVs contain molecules that are specific to a particular organ or disease, EV-based liquid biopsy can be optimized to be highly disease-specific. Such non-invasive tests also allow for a complementary or standalone test, providing rapid diagnosis or prognosis of diseases, such as the FDA approved EV-based biomarker for prostate cancer ExoDX (Tutrone et al., 2020).

Several EV-associated miRNAs such as miR-21, miR-221, and miR-222 have been linked to HCC (Table 2; Figure 2) (Meng et al., 2007; Varnholt et al., 2008; Yang et al., 2014; Sohn et al., 2015). Of interest, Tanaka et al. reported a higher level of EVassociated miR-21 in the sera of cancer patients compared with healthy individuals (Tanaka et al., 2013). Furthermore, the expression of miR-21 was found to be significantly higher in the EVs than that in the EV-depleted sera of patients with HCC, which further suggests that the highly enriched EV-associated miR-21 could be a more reliable diagnostic parameter than free circulating miR-21 in these patients (Table 2) (Wang et al., 2014).
Given that viral-induced liver fibrosis in $\mathrm{HCV}$-infected patients is the primary cause of viral-associated HCC, early detection of liver fibrosis could prove beneficial for the longterm surveillance of HCC. Specifically, EV-associated miR-214 and miR-199a-5p have been reported as potential fibrosisrelated EVs in the liver (Table 2; Figure 2). In one study, downregulation of miR-214 was shown to increase connective tissue growth factor (CCN2), which drives fibrogenesis in activated primary murine HSCs and human HSCs, LX-2 (Chen et al., 2014). Similarly, it was found that miR-199a-5p also works in a similar fashion as miR-214, resulting in reduced levels of EVassociated miR-199a-5p in fibrotic mouse livers and activated primary murine HSCs (Chen et al., 2016). Furthermore, Lambrecht et al. investigated the use of EV-associated miR122, miR-192, and miR-200b for the early staging of hepatic fibrosis in chronic $\mathrm{HBV}$ and $\mathrm{HCV}$ patients and reported increased levels of all three miRNAs in total plasma of earlystage chronic patients (Lambrecht et al., 2017).

\section{Extracellular Vesicles as Therapeutics for Chronic Liver Disease}

In recent years, EVs have attracted enormous attention as a delivery system for therapeutic molecules. Unlike liposomes and nanoparticles, the current preferred carrier choices for drug delivery, EVs are naturally occurring nano-sized biological carriers in a eukaryotic system (Akuma et al., 2019). Due to their cellular origin and small size, EVs are biocompatible, nontoxic, and less immunogenic than liposome-based drug delivery, which make them better candidates than the artificially made liposomes and nanoparticles as drug delivery agents ( Wu et al., 2019). Furthermore, they are able to carry a wide range of biological molecules across biological barriers such as the blood-brain barrier, increasing the bioavailability of the molecules in the biological system and reducing the dosage required for therapeutic benefit (Akuma et al., 2019). The structural composition of EVs also provides a protected enclosed space, making it an ideal delivery carrier for gene therapy, anti-fibrotic and cancer treatments (Wang et al., 2019). However, it is worth mentioning that the use of EVs as a drug delivery system is not without limitations. The feasibility to scale-up primary cell culture to obtain sufficient EVs for clinical use is an important consideration and also a significant challenge (Raimondo et al., 2019). While tumorigenic or immortalized cell lines offer an easier alternative to primary cells for large scale production of EVs, EV-derived from cancer cell lines may inherently pose a risk of undesirable horizontal gene transfer which may have dire consequences in the event that oncogenes are transferred into EVs (Raimondo et al., 2019). Isolating and purifying EVs can also be extremely costly, laborintensive and time-consuming, although the technologies have been continuously improved (Soekmadji et al., 2020).

At present, one of the challenges with the treatment of HCC is the lack of effective therapeutic agents which can successfully improve the overall survival of HCC patients. There are currently six approved drugs available for treatment of HCC with only moderate success (Jindal et al., 2019). Due to the heterogeneity of 
the patient population and increasing number of advanced HCC patients showing drug resistance (Niu et al., 2017; Namee and O'Driscoll, 2018; Wang et al., 2019), there is an urgent need to develop innovative therapy for HCC (Jindal et al., 2019). Takahashi et al. found a role of EV-associated long non-coding RNAs, linc-ROR, in HCC cells which mediate chemoresistance through attenuation of drug-induced apoptosis and inhibition of p53 expression (Takahashi et al., 2014). In light of the need for new and effective cancer therapy, EVs have shown great promise in delivering a common chemotherapeutic agent, paclitaxel to treat multiple drug resistance cells (Kim et al., 2016). Kim et al. demonstrated that there was at least a 50-fold increase in cytotoxicity in drug-resistant cells using the EV-based treatment (Kim et al., 2016). Several studies have also utilized EVs to deliver anti-tumor therapeutics such as methotrexate and doxorubicin to destroy HCC cells (Tang et al., 2012; Tian et al., 2014). Immunotherapy involving EVs as carriers is a promising alternative treatment for HCC. Rao et al. demonstrated a significant reduction in tumor growth in HCC mice treated with HCC-derived EVs which were able to elicit a strong dendritic cellmediated anti-tumor immune response (Figure 2) (Rao et al., 2016). In addition, the tumor microenvironment was also found to have substantially higher levels of infiltrating $\mathrm{CD}^{+} \mathrm{T}$ cells and inflammatory cytokines (Rao et al., 2016).

Viral-induced liver fibrosis and cirrhosis is one of the major risk factors for the development of HCC. Therefore, slowing or halting the progression of hepatic fibrosis will likely be beneficial in reducing the risks for malignancy transformation. Chen et al. found that EV-associated miR-199a-5p derived from quiescent HSCs was able to reduce the expression of fibrogenic genes and proteins in activated HSCs (Figure 2) (Chen et al., 2016). Furthermore, EVs released from adipose-derived mesenchymal stem cells (MSC) transfected with miR-122 were able to inhibit activation and proliferation of HSCs. Interestingly, these MSCderived EVs were also able to inhibit fibrosis in the livers of mice exposed to carbon tetrachloride (Lou et al., 2017). Thus, EVs may have the potential to be used as therapeutics to treat CLD, with further research in this area clearly warranted.

\section{REFERENCES}

Abels, E. R., and Breakefield, X. O. (2016). Introduction to extracellular vesicles: biogenesis, RNA cargo selection, content, release, and uptake. Cell. Mol. Neurobiol. 36 (3), 301-312. doi: 10.1007/s10571-016-0366-Z

Akbar, S. M., Inaba, K., and Onji, M. (1996). Upregulation of MHC class II antigen on dendritic cells from hepatitis B virus transgenic mice by interferon-gamma: abrogation of immune response defect to a T-cell-dependent antigen. Immunology 87 (4), 519-527. doi: 10.1046/j.1365-2567.1996.516576.x

Akers, J. C., Gonda, D., Kim, R., Carter, B. S., and Chen, C. C. (2013). Biogenesis of extracellular vesicles (EV): exosomes, microvesicles, retrovirus-like vesicles, and apoptotic bodies. J. Neuro-Oncol. 113 (1), 1-11. doi: 10.1007/s11060-0131084-8

Akhurst, B., Matthews, V., Husk, K., Smyth, M. J., Abraham, L. J., and Yeoh, G. C. (2005). Differential lymphotoxin-beta and interferon gamma signaling during mouse liver regeneration induced by chronic and acute injury. Hepatology 41 (2), 327-335. doi: 10.1002/hep.20520

Akuma, P., Okagu, O. D., and Udenigwe, C. C. (2019). Naturally occurring exosome vesicles as potential delivery vehicle for bioactive compounds. Front. Sustain. Food Syst. 3 (23). doi: 10.3389/fsufs.2019.00023

\section{CONCLUSIONS AND FUTURE DIRECTIONS}

EVs represent a novel class of nanoparticles, which could be involved in the pathogenesis and progression of CLD. Indeed, evidence gathered from recent studies has shed light on the role of EVs in viral-associated CLD and HCC. EVs have emerged as an important, yet poorly understood mechanism utilized by viruses and the host immune system for disease pathogenesis of viralassociated CLD and HCC. While there is evidence that EVs have the potential to play a role as non-invasive diagnostic tools for early detection of disease and as carriers for therapeutics, a more thorough understanding of EV biogenesis and disease pathogenesis and better, internationally standardized technologies for the isolation and enrichment of EVs are warranted before they can be widely used in the clinic for the treatment of CLD.

\section{AUTHOR CONTRIBUTIONS}

All authors contributed to the article and approved the submitted version.

\section{ACKNOWLEDGMENTS}

This work was supported by the US Department of Defense Congressionally Directed Medical Research Program Prostate Cancer Research Program Idea Development Award [Number: W81XWH-16-1-0736] to CS from the Office of the Assistant Secretary of Defense for Health Affairs. Opinions, interpretations, conclusions and recommendations are those of the author and are not necessarily endorsed by the DoD. This work was also supported by a Senior Research Fellowship to GR from the National Health and Medical Research Council of Australia (\#APP1061332). The authors are very grateful for the help with the illustrations received from Madeleine Flynn (QIMR Berghofer).

Andreu, Z., and Yáñez-Mó, M. (2014). Tetraspanins in extracellular vesicle formation and function. Front. Immunol. 5, 442. doi: 10.3389/fimmu. 2014.00442

Bai, Q., An, J., Wu, X., You, H., Ma, H., Liu, T., et al. (2012). HBV promotes the proliferation of hepatic stellate cells via the PDGF-B/PDGFR- $\beta$ signaling pathway in vitro. Int. J. Mol. Med. 30 (6), 1443-1450. doi: 10.3892/ijmm.2012.1148

Banales, J. M., Feldstein, A. E., Sänger, H., Lukacs-Kornek, V., Szabo, G., and Kornek, M. (2019). Extracellular vesicles in liver diseases: meeting report from the International Liver Congress 2018. Hepatol. Commun. 3 (2), 305-315. doi: 10.1002/hep4.1300

Bartneck, M., Warzecha, K. T., and Tacke, F. (2014). Therapeutic targeting of liver inflammation and fibrosis by nanomedicine. Hepatobiliary Surg. Nutr. 3 (6), 364-376. doi: 10.3978/j.issn.2304-3881.2014.11.02

Bartosch, B., Vitelli, A., Granier, C., Goujon, C., Dubuisson, J., Pascale, S., et al. (2003). Cell entry of hepatitis $C$ virus requires a set of co-receptors that include the CD81 tetraspanin and the SR-B1 scavenger receptor. J. Biol. Chem. 278 (43), 41624-41630. doi: 10.1074/jbc.M305289200

Best, J., Dollé, L., Manka, P., Coombes, J., van Grunsven, L. A., and Syn, W.-K. (2013). Role of liver progenitors in acute liver injury. Front. Physiol. 4, 258. doi: 10.3389/fphys.2013.00258 
Bird, T. G., Lu, W. Y., Boulter, L., Gordon-Keylock, S., Ridgway, R. A., Williams, M. J., et al. (2013). Bone marrow injection stimulates hepatic ductular reactions in the absence of injury via macrophage-mediated TWEAK signaling. Proc. Natl. Acad. Sci. U. S. A. 110 (16), 6542-6547. doi: 10.1073/ pnas. 1302168110

Block, T. M., Mehta, A. S., Fimmel, C. J., and Jordan, R. (2003). Molecular viral oncology of hepatocellular carcinoma. Oncogene 22 (33), 5093-5107. doi: 10.1038/sj.onc. 1206557

Bonilla Guerrero, R., and Roberts, L. R. (2005). The role of hepatitis B virus integrations in the pathogenesis of human hepatocellular carcinoma. J. Hepatol. 42 (5), 760-777. doi: 10.1016/j.jhep.2005.02.005

Boulter, L., Govaere, O., Bird, T. G., Radulescu, S., Ramachandran, P., Pellicoro, A., et al. (2012). Macrophage-derived Wnt opposes Notch signaling to specify hepatic progenitor cell fate in chronic liver disease. Nat. Med. 18 (4), 572-579. doi: $10.1038 / \mathrm{nm} .2667$

Bridle, K. R., Crawford, D. H., Powell, L. W., and Ramm, G. A. (2001). Role of myofibroblasts in tumour encapsulation of hepatocellular carcinoma in haemochromatosis. Liver 21 (2), 96-104. doi: 10.1034/j.1600-0676.2001. 021002096.x

Buchmann, P., Dembek, C., Kuklick, L., Jäger, C., Tedjokusumo, R., von Freyend, M. J., et al. (2013). A novel therapeutic hepatitis B vaccine induces cellular and humoral immune responses and breaks tolerance in hepatitis B virus (HBV) transgenic mice. Vaccine 31 (8), 1197-1203. doi: 10.1016/j.vaccine.2012.12.074

Byass, P. (2014). The global burden of liver disease: a challenge for methods and for public health. BMC MWorld J. Gastroenterol. Med. 12, 159. doi: 10.1186/ s12916-014-0159-5

Cao, L.-Q., Yang, X.-W., Chen, Y.-B., Zhang, D.-W., Jiang, X.-F., and Xue, P. (2019). Exosomal miR-21 regulates the TETs/PTENp1/PTEN pathway to promote hepatocellular carcinoma growth. Mol. Cancer 18 (1), 148-148. doi: 10.1186/s12943-019-1075-2

Cartier, V., and Aubé, C. (2014). Diagnosis of hepatocellular carcinoma. Diagn. Interventional Imaging 95 (7), 709-719. doi: 10.1016/j.diii.2014.06.004

Chargaff, E., and West, R. (1946). The biological significance of the thromboplastic protein of blood. J. Biol. Chem. 166 (1), 189-197.

Chayanupatkul, M., Omino, R., Mittal, S., Kramer, J. R., Richardson, P., Thrift, A. P., et al. (2017). Hepatocellular carcinoma in the absence of cirrhosis in patients with chronic hepatitis B virus infection. J. Hepatol. 66 (2), 355-362. doi: 10.1016/j.jhep.2016.09.013

Chen, Y., and Tian, Z. (2019). HBV-induced immune imbalance in the development of HCC. Front. Immunol. 10, 2048. doi: 10.3389/fimmu. 2019.02048

Chen, L., Charrier, A., Zhou, Y., Chen, R., Yu, B., Agarwal, K., et al. (2014). Epigenetic regulation of connective tissue growth factor by MicroRNA-214 delivery in exosomes from mouse or human hepatic stellate cells. Hepatol. (Baltimore Md.) 59 (3), 1118-1129. doi: 10.1002/hep.26768

Chen, L., Chen, R., Velazquez, V. M., and Brigstock, D. R. (2016). Fibrogenic signaling is suppressed in hepatic stellate cells through targeting of connective tissue growth factor (CCN2) by cellular or exosomal microRNA-199a-5p. Am. J. Pathol. 186 (11), 2921-2933. doi: 10.1016/j.ajpath.2016.07.011

Clouston, A. D., Powell, E. E., Walsh, M. J., Richardson, M. M., Demetris, A. J., and Jonsson, J. R. (2005). Fibrosis correlates with a ductular reaction in hepatitis C: roles of impaired replication, progenitor cells and steatosis. Hepatology 41 (4), 809-818. doi: 10.1002/hep.20650

Colombo, M., Raposo, G., and Théry, C. (2014). Biogenesis, secretion, and intercellular interactions of exosomes and other extracellular vesicles. Annu. Rev. Cell Dev. Biol. 30 (1), 255-289. doi: 10.1146/annurev-cellbio-101512122326

Cooper, S., Erickson, A. L., Adams, E. J., Kansopon, J., Weiner, A. J., Chien, D. Y., et al. (1999). Analysis of a successful immune response against hepatitis $C$ virus. Immunity 10 (4), 439-449. doi: 10.1016/s1074-7613(00)80044-8

Crotta, S., Stilla, A., Wack, A., D’Andrea, A., Nuti, S., D’Oro, U., et al. (2002). Inhibition of natural killer cells through engagement of CD81 by the major hepatitis C virus envelope protein. J. Exp. Med. 195 (1), 35-41. doi: 10.1084/ jem.20011124

Deleve, L. D., Wang, X., and Guo, Y. (2008a). Sinusoidal endothelial cells prevent rat stellate cell activation and promote reversion to quiescence. Hepatology 48 (3), 920-930. doi: 10.1002/hep.22351
DeLeve, L. D., Wang, X., Kanel, G. C., Atkinson, R. D., and McCuskey, R. S. (2008b). Prevention of hepatic fibrosis in a murine model of metabolic syndrome with nonalcoholic steatohepatitis. Am. J. Pathol. 173 (4), $993-$ 1001. doi: 10.2353/ajpath.2008.070720

Deng, F., Magee, N., and Zhang, Y. (2017). Decoding the role of extracellular vesicles in liver diseases. Liver Res. 1 (3), 147-155. doi: 10.1016/j.livres. 2017.11.003

Devhare, P. B., Sasaki, R., Shrivastava, S., Di Bisceglie, A. M., Ray, R., and Ray, R. B. (2017). Exosome-mediated intercellular communication between hepatitis C virus-infected hepatocytes and hepatic stellate cells. J. Virol. 91 (6), e02225e02216. doi: 10.1128/JVI.02225-16

Dollé, L., Best, J., Mei, J., Al Battah, F., Reynaert, H., van Grunsven, L. A., et al. (2010). The quest for liver progenitor cells: a practical point of view. J. Hepatol. 52 (1), 117-129. doi: 10.1016/j.jhep.2009.10.009

Dreux, M., Garaigorta, U., Boyd, B., Décembre, E., Chung, J., Whitten-Bauer, C., et al. (2012). Short-range exosomal transfer of viral RNA from infected cells to plasmacytoid dendritic cells triggers innate immunity. Cell Host Microbe 12 (4), 558-570. doi: 10.1016/j.chom.2012.08.010

Dukers, D. F., Meij, P., Vervoort, M. B., Vos, W., Scheper, R. J., Meijer, C. J., et al. (2000). Direct immunosuppressive effects of EBV-encoded latent membrane protein 1. J. Immunol. 165 (2), 663-670. doi: 10.4049/jimmunol.165.2.663

Dwyer, B. J., Olynyk, J. K., Ramm, G. A., and Tirnitz-Parker, J. E. E. (2014) TWEAK and LT $\beta$ signaling during chronic liver disease. Front. Immunol. 5, 39. doi: 10.3389/fimmu.2014.00039

Earnest, J. T., Hantak, M. P., Park, J.-E., and Gallagher, T. (2015). Coronavirus and influenza virus proteolytic priming takes place in tetraspanin-enriched membrane microdomains. J. Virol. 89 (11), 6093-6104. doi: 10.1128/ jvi.00543-15

Earnest, J. T., Hantak, M. P., Li, K., McCray, P. B.Jr., Perlman, S., and Gallagher, T. (2017). The tetraspanin CD9 facilitates MERS-coronavirus entry by scaffolding host cell receptors and proteases. PloS Pathogen 13 (7), e1006546. doi: 10.1371/ journal.ppat.1006546

El-Awady, M. K., Tabll, A. A., Redwan el, R. M., Youssef, S., Omran, M. H., Thakeb, F., et al. (2005). Flow cytometric detection of hepatitis $C$ virus antigens in infected peripheral blood leukocytes: binding and entry. World J. Gastroenterol. 11 (33), 5203-5208. doi: 10.3748/wjg.v11.i33.5203. Flow cytometric detection of hepatitis $\mathrm{C}$ virus antigens in infected peripheral blood leukocytes: binding and entry.

El-Serag, H. B., and Mason, A. C. (1999). Rising incidence of hepatocellular carcinoma in the United States. New Engl. J. Med. 340 (10), 745-750. doi: 10.1056/nejm199903113401001

El-Serag, H. B., and Rudolph, K. L. (2007). Hepatocellular carcinoma: epidemiology and molecular carcinogenesis. Gastroenterology 132 (7), 25572576. doi: 10.1053/j.gastro.2007.04.061

Fattovich, G., Pantalena, M., Zagni, I., Realdi, G., Schalm, S. W., and Christensen, E. (2002). Effect of hepatitis B and C virus infections on the natural history of compensated cirrhosis: a cohort study of 297 patients. Am. J. Gastroenterol. 97 (11), 2886-2895. doi: 10.1111/j.1572-0241.2002.07057.x

Feitelson, M. A., and Lee, J. (2007). Hepatitis B virus integration, fragile sites, and hepatocarcinogenesis. Cancer Lett. 252 (2), 157-170. doi: 10.1016/j.canlet. 2006.11.010

Fénéant, L., Levy, S., and Cocquerel, L. (2014). CD81 and hepatitis C virus (HCV) infection. Viruses 6 (2), 535-572. doi: 10.3390/v6020535

Ferri, C., Ramos-Casals, M., Zignego, A. L., Arcaini, L., Roccatello, D., Antonelli, A., et al. (2016). International diagnostic guidelines for patients with HCV-related extrahepatic manifestations. A multidisciplinary expert statement. Autoimmun. Rev. 15 (12), 1145-1160. doi: 10.1016/j.autrev. 2016.09.006

Fiorotto, R., Raizner, A., Morell, C. M., Torsello, B., Scirpo, R., Fabris, L., et al. (2013). Notch signaling regulates tubular morphogenesis during repair from biliary damage in mice. J. Hepatol. 59 (1), 124-130. doi: 10.1016/j.jhep. 2013.02.025

Flanagan, J., Middeldorp, J., and Sculley, T. (2003). Localization of the EpsteinBarr virus protein LMP 1 to exosomes. J. Gen. Virol. 84 (7), 1871-1879. doi: 10.1099/vir.0.18944-0

Friedman, S. L. (2008). Hepatic stellate cells: protean, multifunctional, and enigmatic cells of the liver. Physiol. Rev. 88 (1), 125-172. doi: 10.1152/ physrev.00013.2007 
Fu, E., Pan, L., Xie, Y., Mu, D., Liu, W., Jin, F., et al. (2015). Tetraspanin CD63 is a regulator of HIV-1 replication. Int. J. Clin. Exp. Pathol. 8 (2), 1184-1198.

Furuyama, K., Kawaguchi, Y., Akiyama, H., Horiguchi, M., Kodama, S., Kuhara, T., et al. (2011). Continuous cell supply from a Sox9-expressing progenitor zone in adult liver, exocrine pancreas and intestine. Nat. Genet. 43 (1), 34-41. doi: $10.1038 /$ ng.722

Gabay, C. (2006). Interleukin-6 and chronic inflammation. Arthritis Res. Ther. 8 Suppl 2 (Suppl 2), S3-S3. doi: 10.1186/ar1917

Gately, M. K., Renzetti, L. M., Magram, J., Stern, A. S., Adorini, L., Gubler, U., et al. (1998). The interleukin-12/interleukin-12-receptor system: role in normal and pathologic immune responses. Annu. Rev. Immunol. 16, 495-521. doi: 10.1146/ annurev.immunol.16.1.495

Geerts, A. (2001). History, heterogeneity, developmental biology, and functions of quiescent hepatic stellate cells. Semin. Liver Dis. 21 (3), 311-335. doi: 10.1055/ s-2001-17550

Golabi, P., Fazel, S., Otgonsuren, M., Sayiner, M., Locklear, C. T., and Younossi, Z. M. (2017). Mortality assessment of patients with hepatocellular carcinoma according to underlying disease and treatment modalities. Medicine 96 (9), e5904-e5904. doi: 10.1097/MD.0000000000005904

Grimm, D., Thimme, R., and Blum, H. E. (2011). HBV life cycle and novel drug targets. Hepatol. Int. 5 (2), 644-653. doi: 10.1007/s12072-011-9261-3

Harwood, N. M. K., Golden-Mason, L., Cheng, L., Rosen, H. R., and Mengshol, J. A. (2016). HCV-infected cells and differentiation increase monocyte immunoregulatory galectin-9 production. J. Leukocyte Biol. 99 (3), 495-503. doi: 10.1189/jlb.5A1214-582R

Higashi, N., Sato, M., Kojima, N., Irie, T., Kawamura, K., Mabuchi, A., et al. (2005). Vitamin A storage in hepatic stellate cells in the regenerating rat liver: with special reference to zonal heterogeneity. Anatomical Record Part A. Discov. Mol. Cell. Evolution. Biol. 286 (2), 899-907. doi: 10.1002/ar.a.20230

Higashi, T., Friedman, S. L., and Hoshida, Y. (2017). Hepatic stellate cells as key target in liver fibrosis. Adv. Drug Deliv. Rev. 121, 27-42. doi: 10.1016/ j.addr.2017.05.007

Hirsova, P., Ibrahim, S. H., Verma, V. K., Morton, L. A., Shah, V. H., LaRusso, N. F., et al. (2016). Extracellular vesicles in liver pathobiology: Small particles with big impact. Hepatology 64 (6), 2219-2233. doi: 10.1002/hep.28814

Honegger, A., Leitz, J., Bulkescher, J., Hoppe-Seyler, K., and Hoppe-Seyler, F. (2013). Silencing of human papillomavirus (HPV) E6/E7 oncogene expression affects both the contents and the amounts of extracellular microvesicles released from HPV-positive cancer cells. Int. J. Cancer 133 (7), 1631-1642. doi: 10.1002/ijc.28164

Horn, T., Christoffersen, P., and Henriksen, J. H. (1987). Alcoholic liver injury: defenestration in noncirrhotic livers-a scanning electron microscopic study. Hepatology 7 (1), 77-82. doi: 10.1002/hep.1840070117

Hoshino, A., Kim, H. S., Bojmar, L., Gyan, K. E., Cioffi, M., Hernandez, J., et al. (2020). Extracellular vesicle and particle biomarkers define multiple human cancers. Cell 182 (4), 1044-1061.e1018. doi: 10.1016/j.cell.2020.07.009

Irshad, M., Mankotia, D. S., and Irshad, K. (2013). An insight into the diagnosis and pathogenesis of hepatitis C virus infection. World J. Gastroenterol. 19 (44), 7896-7909. doi: 10.3748/wjg.v19.i44.7896

Jeffrey, G. P., Gordon, L. G., Hill, M. M., and Ramm, G. A. (2020). Liquid biopsies for hepatocellular cancer and their potential in clinical practice. Hepatology 71 (6), 2160-2162. doi: 10.1002/hep.31168

Jindal, A., Thadi, A., and Shailubhai, K. (2019). Hepatocellular carcinoma: etiology and current and future drugs. J. Clin. Exp. Hepatol. 9 (2), 221-232. doi: 10.1016/j.jceh.2019.01.004

Kakizaki, M., Yamamoto, Y., Yabuta, S., Kurosaki, N., Kagawa, T., and Kotani, A. (2018). The immunological function of extracellular vesicles in hepatitis B virus-infected hepatocytes. PloS One 13 (12), e0205886. doi: 10.1371/ journal.pone.0205886

Karidis, N. P., Delladetsima, I., and Theocharis, S. (2015). Hepatocyte turnover in chronic HCV-induced liver injury and cirrhosis. Gastroenterol. Res. Pract. 2015:654105. doi: 10.1155/2015/654105

Khatun, M., and Ray, R. B. (2019). Mechanisms underlying hepatitis C virusassociated hepatic fibrosis. Cells 8 (10), 1249. doi: 10.3390/cells8101249

Kim, M. S., Haney, M. J., Zhao, Y., Mahajan, V., Deygen, I., Klyachko, N. L., et al. (2016). Development of exosome-encapsulated paclitaxel to overcome MDR in cancer cells. Nanomedicine 12 (3), 655-664. doi: 10.1016/j.nano. 2015.10.012
Knight, B., Matthews, V. B., Akhurst, B., Croager, E. J., Klinken, E., Abraham, L. J., et al. (2005). Liver inflammation and cytokine production, but not acute phase protein synthesis, accompany the adult liver progenitor (oval) cell response to chronic liver injury. Immunol. Cell Biol. 83 (4), 364-374. doi: 10.1111/j.14401711.2005.01346.x

Knouf, E. C., Metzger, M. J., Mitchell, P. S., Arroyo, J. D., Chevillet, J. R., Tewari, M., et al. (2009). Multiple integrated copies and high-level production of the human retrovirus XMRV (Xenotropic Murine leukemia virus-Related Virus) from 22Rv1 prostate carcinoma cells. J. Virol. 83 (14), 7353-7356. doi: 10.1128/ jvi.00546-09

Kobayashi, M., Ikeda, K., Hosaka, T., Sezaki, H., Someya, T., Akuta, N., et al. (2006). Natural history of compensated cirrhosis in the Child-Pugh class A compared between 490 patients with hepatitis C and 167 with B virus infections. J. Med. Virol. 78 (4), 459-465. doi: 10.1002/jmv.20562

Köhn-Gaone, J., Gogoi-Tiwari, J., Ramm, G. A., Olynyk, J. K., and Tirnitz-Parker, J. E. (2016). The role of liver progenitor cells during liver regeneration, fibrogenesis, and carcinogenesis. Am. J. Physiol. 310 (3), G143-G154. doi: 10.1152/ajpgi.00215.2015

Kouwaki, T., Fukushima, Y., Daito, T., Sanada, T., Yamamoto, N., Mifsud, E. J., et al. (2016). Extracellular vesicles including exosomes regulate innate immune responses to hepatitis B virus infection. Front. Immunol. 7:335. doi: 10.3389/ fimmu.2016.00335

Krajden, M., McNabb, G., and Petric, M. (2005). The laboratory diagnosis of hepatitis B virus. Can. J. Infect. Dis. Med. Microbiol. 16 (2), 65-72. doi: 10.1155/ 2005/450574

Lambrecht, J., Jan Poortmans, P., Verhulst, S., Reynaert, H., Mannaerts, I., and van Grunsven, L. A. (2017). Circulating ECV-associated miRNAs as potential clinical biomarkers in early stage HBV and HCV induced liver fibrosis. Front. Pharmacol. 8:56. doi: 10.3389/fphar.2017.00056

Lara-Pezzi, E., Majano, P. L., Gómez-Gonzalo, M., García-Monzón, C., MorenoOtero, R., Levrero, M., et al. (1998). The hepatitis B virus X protein upregulates tumor necrosis factor alpha gene expression in hepatocytes. Hepatology 28 (4), 1013-1021. doi: 10.1002/hep.510280416

Lee, S. G., and Rho, H. M. (2000). Transcriptional repression of the human p53 gene by hepatitis B viral X protein. Oncogene 19 (3), 468-471. doi: 10.1038/ sj.onc. 1203312

Lee, Y., Park, U. S., Choi, I., Yoon, S. K., Park, Y. M., and Lee, Y. I. (1998). Human interleukin 6 gene is activated by hepatitis B virus-X protein in human hepatoma cells. Clin. Cancer Res. 4 (7), 1711-1717.

Lee, M., Lee, M., Lee, S. K., Son, M., Cho, S. W., Park, S., et al. (1999). Expression of Th1 and Th2 type cytokines responding to HBsAg and HBxAg in chronic hepatitis B patients. J. Korean Med. Sci. 14 (2), 175-181. doi: 10.3346/ jkms.1999.14.2.175

Lee, C. M., Knight, B., Yeoh, G. C., Ramm, G. A., and Olynyk, J. K. (2005). Lymphotoxin-beta production following bile duct ligation: possible role for Kupffer cells. J. Gastroenterol. Hepatol. 20 (11), 1762-1768. doi: 10.1111/ j.1440-1746.2005.04065.x

Lee, M. J., Jin, Y.-H., Kim, K., Choi, Y., Kim, H.-C., and Park, S. (2010). Expression of hepatitis B virus $\mathrm{x}$ protein in hepatocytes suppresses CD8 T cell activity. Immune Netw. 10 (4), 126-134. doi: 10.4110/in.2010.10.4.126

Lee, J.-H., Schierer, S., Blume, K., Dindorf, J., Wittki, S., Xiang, W., et al. (2016). HIV-Nef and ADAM17-containing plasma extracellular vesicles induce and correlate with immune pathogenesis in chronic HIV infection. EBioMedicine 6, 103-113. doi: 10.1016/j.ebiom.2016.03.004

Lenassi, M., Cagney, G., Liao, M., Vaupotic, T., Bartholomeeusen, K., Cheng, Y., et al. (2010). HIV Nef is secreted in exosomes and triggers apoptosis in bystander CD4+ T cells. Traffic 11 (1), 110-122. doi: 10.1111/j.1600-0854. 2009.01006.x

Lewindon, P. J., Pereira, T. N., Hoskins, A. C., Bridle, K. R., Williamson, R. M., Shepherd, R. W., et al. (2002). The role of hepatic stellate cells and transforming growth factor- $\beta 1$ in cystic Ffbrosis liver disease. Am. J. Pathol. 160 (5), 1705-1715. doi: 10.1016/S0002-9440(10)61117-0

Liang, T. J. (2009). Hepatitis B: the virus and disease. Hepatology 49 (5 Suppl), S13-S21. doi: 10.1002/hep.22881

Lingala, S., and Ghany, M. G. (2015). Natural history of hepatitis C. Gastroenterol. Clinics North America 44 (4), 717-734. doi: 10.1016/j.gtc.2015.07.003

Liu, G., Ouyang, X., Sun, Y., Xiao, Y., You, B., Gao, Y., et al. (2020). The miR-92a$2-5 p$ in exosomes from macrophages increases liver cancer cells invasion via 
altering the AR/PHLPP/p-AKT/ $\beta$-catenin signaling. Cell Death Different. doi: 10.1038/s41418-020-0575-3

Lou, G., Yang, Y., Liu, F., Ye, B., Chen, Z., Zheng, M., et al. (2017). MiR-122 modification enhances the therapeutic efficacy of adipose tissue-derived mesenchymal stem cells against liver fibrosis. J. Cell. Mol. Med. 21 (11), 2963-2973. doi: 10.1111/jcmm.13208

Lowes, K. N., Croager, E. J., Abraham, L. J., Olynyk, J. K., and Yeoh, G. C. T. (2003). Upregulation of lymphotoxin beta expression in liver progenitor (oval) cells in chronic hepatitis C. Gut 52 (9), 1327-1332. doi: 10.1136/gut. 52.9.1327

Lozano-Andrés, E., Libregts, S. F., Toribio, V., Royo, F., Morales, S., López-Martín, S., et al. (2019). Tetraspanin-decorated extracellular vesicle-mimetics as a novel adaptable reference material. J. Extracellular Vesicles 8 (1), 1573052-1573052. doi: 10.1080/20013078.2019.1573052

Mahé, Y., Mukaida, N., Kuno, K., Akiyama, M., Ikeda, N., Matsushima, K., et al. (1991). Hepatitis B virus X protein transactivates human interleukin-8 gene through acting on nuclear factor $\mathrm{kB}$ and CCAAT/enhancer-binding proteinlike cis-elements. J. Biol. Chem. 266 (21), 13759-13763.

Maini, M. K., Boni, C., Lee, C. K., Larrubia, J. R., Reignat, S., Ogg, G. S., et al. (2000). The role of virus-specific CD8(+) cells in liver damage and viral control during persistent hepatitis B virus infection. J. Exp. Med. 191 (8), 1269-1280. doi: $10.1084 /$ jem.191.8.1269

Marinos, G., Torre, F., Chokshi, S., Hussain, M., Clarke, B. E., Rowlands, D. J., et al. (1995). Induction of T-helper cell response to hepatitis B core antigen in chronic hepatitis B: a major factor in activation of the host immune response to the hepatitis B virus. Hepatology 22 (4 Pt 1), 1040-1049. doi: 10.1016/02709139(95)90607-x

Martín-Vílchez, S., Sanz-Cameno, P., Rodríguez-Muñoz, Y., Majano, P. L., Molina-Jiménez, F., López-Cabrera, M., et al. (2008). The hepatitis B virus X protein induces paracrine activation of human hepatic stellate cells. Hepatology 47 (6), 1872-1883. doi: 10.1002/hep.22265

Mattox, A. K., Bettegowda, C., Zhou, S., Papadopoulos, N., Kinzler, K. W., and Vogelstein, B. (2019). Applications of liquid biopsies for cancer. Sci. Trans. Med. 11 (507), eaay1984. doi: 10.1126/scitranslmed.aay1984

McGlynn, K. A., and London, W. T. (2011). The global epidemiology of hepatocellular carcinoma: present and future. Clin. Liver Dis. 15 (2), 223243, vii-x. doi: 10.1016/j.cld.2011.03.006

McGlynn, K. A., Petrick, J. L., and London, W. T. (2015). Global epidemiology of hepatocellular carcinoma: an emphasis on demographic and regional variability. Clin. Liver Dis. 19 (2), 223-238. doi: 10.1016/j.cld.2015.01.001

McKeating, C., Cadden, I., McDougall, N., Jessop, L., Quah, S., Lavelle, M., et al. (2018). Progression from acute to chronic hepatitis B is more common in older adults. Ulster Med. J. 87 (3), 177-180.

Meng, F., Henson, R., Wehbe-Janek, H., Ghoshal, K., Jacob, S. T., and Patel, T. (2007). MicroRNA-21 regulates expression of the PTEN tumor suppressor gene in human hepatocellular cancer. Gastroenterology 133 (2), 647-658. doi: 10.1053/j.gastro.2007.05.022

Mengshol, J. A., Golden-Mason, L., Arikawa, T., Smith, M., Niki, T., McWilliams, R., et al. (2010). A crucial role for Kupffer cell-derived galectin-9 in regulation of T cell immunity in hepatitis C infection. PloS One 5 (3), e9504-e9504. doi: 10.1371/journal.pone.0009504

Minami, M., Daimon, Y., Mori, K., Takashima, H., Nakajima, T., Itoh, Y., et al. (2005). Hepatitis B virus-related insertional mutagenesis in chronic hepatitis B patients as an early drastic genetic change leading to hepatocarcinogenesis. Oncogene 24 (27), 4340-4348. doi: 10.1038/sj.onc.1208628

Moreira, R. K. (2007). Hepatic stellate cells and liver fibrosis. Arch. Pathol. Lab. Med. 131 (11), 1728-1734. doi: 10.1043/1543-2165(2007)131[1728:hscalf] 2.0.co;2

Nakamoto, Y., Guidotti, L. G., Kuhlen, C. V., Fowler, P., and Chisari, F. V. (1998). Immune pathogenesis of hepatocellular carcinoma. J. Exp. Med. 188 (2), 341350. doi: $10.1084 /$ jem.188.2.341

Namee, N. M., and O'Driscoll, L. (2018). Extracellular vesicles and anti-cancer drug resistance. Biochim. Biophys. Acta (BBA) Rev. Cancer 1870 (2), 123-136. doi: 10.1016/j.bbcan.2018.07.003

Narayanan, A., Iordanskiy, S., Das, R., Van Duyne, R., Santos, S., Jaworski, E., et al. (2013). Exosomes derived from HIV-1-infected cells contain trans-activation response element RNA. J. Biol. Chem. 288 (27), 20014-20033. doi: 10.1074/ jbc.M112.438895
Ni, Y., Lempp, F. A., Mehrle, S., Nkongolo, S., Kaufman, C., Fälth, M., et al. (2014). Hepatitis B and D viruses exploit sodium taurocholate co-transporting polypeptide for species-specific entry into hepatocytes. Gastroenterology 146 (4), 1070-1083. doi: 10.1053/j.gastro.2013.12.024

Ni, Y., Li, J.-M., Liu, M.-K., Zhang, T.-T., Wang, D.-P., Zhou, W.-H., et al. (2017). Pathological process of liver sinusoidal endothelial cells in liver diseases. World J. Gastroenterol. 23 (43), 7666-7677. doi: 10.3748/wjg.v23.i43.7666

Niu, L., Liu, L., Yang, S., Ren, J., Lai, P. B. S., and Chen, G. G. (2017). New insights into sorafenib resistance in hepatocellular carcinoma: Responsible mechanisms and promising strategies. Biochim. Biophys. Acta (BBA) 1868 (2), 564-570. doi: 10.1016/j.bbcan.2017.10.002

Nolte-'t Hoen, E., Cremer, T., Gallo, R. C., and Margolis, L. B. (2016). Extracellular vesicles and viruses: are they close relatives? Proc. Natl. Acad. Sci. U. States America 113 (33), 9155-9161. doi: 10.1073/pnas.1605146113

Patel, K., and Sebastiani, G. (2020). Limitations of non-invasive tests for assessment of liver fibrosis. JHEP Rep. 2 (2), 100067. doi: 10.1016/ j.jhepr.2020.100067

Pelchen-Matthews, A., Kramer, B., and Marsh, M. (2003). Infectious HIV-1 assembles in late endosomes in primary macrophages. J. Cell Biol. 162 (3), 443-455. doi: 10.1083/jcb.200304008

Penna, A., Pilli, M., Zerbini, A., Orlandini, A., Mezzadri, S., Sacchelli, L., et al. (2007). Dysfunction and functional restoration of HCV-specific CD8 responses in chronic hepatitis C virus infection. Hepatology 45 (3), 588-601. doi: $10.1002 /$ hep.21541

Pozniak, K. N., Pearen, M. A., Pereira, T. N., Kramer, C. S. M., Kalita-De Croft, P., Nawaratna, S. K., et al. (2017). Taurocholate induces biliary differentiation of liver progenitor cells causing hepatic stellate cell chemotaxis in the ductular reaction: role in pediatric cystic fibrosis liver disease. Am. J. Pathol. 187 (12), 2744-2757. doi: 10.1016/j.ajpath.2017.08.024

Qu, C., Wang, Y., Wang, P., Chen, K., Wang, M., Zeng, H., et al. (2019). Detection of early-stage hepatocellular carcinoma in asymptomatic HBsAg-seropositive individuals by liquid biopsy. Proc. Natl. Acad. Sci. U. S. A. 116 (13), 6308-6312. doi: 10.1073/pnas.1819799116

Radziewicz, H., Ibegbu, C. C., Fernandez, M. L., Workowski, K. A., Obideen, K., Wehbi, M., et al. (2007). Liver-infiltrating lymphocytes in chronic human hepatitis $\mathrm{C}$ virus infection display an exhausted phenotype with high levels of PD-1 and low levels of CD127 expression. J. Virol. 81 (6), 2545-2553. doi: 10.1128/JVI.02021-06

Raimondo, S., Giavaresi, G., Lorico, A., and Alessandro, R. (2019). Extracellular vesicles as biological shuttles for targeted therapies. Int. J. Mol. Sci. 20 (8), 1848. doi: $10.3390 /$ ijms 20081848

Rajbhandari, R., and Chung, R. T. (2016). Treatment of hepatitis B: a concise review. Clin. Trans. Gastroenterol. 7 (9), e190-e190. doi: 10.1038/ctg.2016.46

Ramakrishnaiah, V., Thumann, C., Fofana, I., Habersetzer, F., Pan, Q., de Ruiter, P. E., et al. (2013). Exosome-mediated transmission of hepatitis C virus between human hepatoma Huh7.5 cells. Proc. Natl. Acad. Sci. U. S. A. 110 (32), 13109-13113. doi: 10.1073/pnas.1221899110

Ramm, G. A., Crawford, D. H. G., Powell, L. W., Walker, N. I., Fletcher, L. M., and Halliday, J. W. (1997). Hepatic stellate cell activation in genetic haemochromatosis: Lobular distribution, effect of increasing hepatic iron and response to phlebotomy. J. Hepatol. 26 (3), 584-592. doi: 10.1016/S0168-8278 (97) $80424-2$

Ramm, G. A., Nair, V. G., Bridle, K. R., Shepherd, R. W., and Crawford, D. H. G. (1998). Contribution of hepatic parenchymal and nonparenchymal cells to hepatic fibrogenesis in biliary atresia. Am. J. Pathol. 153 (2), 527-535. doi: 10.1016/S0002-9440(10)65595-2

Rao, Q., Zuo, B., Lu, Z., Gao, X., You, A., Wu, C., et al. (2016). Tumor-derived exosomes elicit tumor suppression in murine hepatocellular carcinoma models and humans in vitro. Hepatology 64 (2), 456-472. doi: 10.1002/hep.28549

Ringelhan, M., McKeating, J. A., and Protzer, U. (2017). Viral hepatitis and liver cancer. Philos. Trans. R. Soc. Biol. Sci. 372 (1732), 20160274. doi: 10.1098/ rstb.2016.0274

Ruddell, R. G., Knight, B., Tirnitz-Parker, J. E., Akhurst, B., Summerville, L., Subramaniam, V. N., et al. (2009). Lymphotoxin-beta receptor signaling regulates hepatic stellate cell function and wound healing in a murine model of chronic liver injury. Hepatology 49 (1), 227-239. doi: 10.1002/hep.22597

Sampey, G. C., Saifuddin, M., Schwab, A., Barclay, R., Punya, S., Chung, M.-C., et al. (2016). Exosomes from HIV-1-infected Cells Stimulate Production of 
Pro-inflammatory Cytokines through Trans-activating Response (TAR) RNA. J. Biol. Chem. 291 (3), 1251-1266. doi: 10.1074/jbc.M115.662171

Sanada, T., Hirata, Y., Naito, Y., Yamamoto, N., Kikkawa, Y., Ishida, Y., et al. (2016). Transmission of HBV DNA Mediated by Ceramide-Triggered Extracellular Vesicles. Cell. Mol. Gastroenterol. Hepatol. 3 (2), 272-283. doi: 10.1016/j.jcmgh.2016.10.003

Scharton-Kersten, T., Afonso, L. C., Wysocka, M., Trinchieri, G., and Scott, P. (1995). IL-12 is required for natural killer cell activation and subsequent T helper 1 cell development in experimental leishmaniasis. J. Immunol. 154 (10), 5320-5330.

Scheffer, K. D., Gawlitza, A., Spoden, G. A., Zhang, X. A., Lambert, C., Berditchevski, F., et al. (2013). Tetraspanin CD151 mediates papillomavirus type 16 endocytosis. J. Virol. 87 (6), 3435-3446. doi: 10.1128/jvi.02906-12

Schorey, J. S., Cheng, Y., Singh, P. P., and Smith, V. L. (2015). Exosomes and other extracellular vesicles in host-pathogen interactions. EMBO Rep. 16 (1), 24-43. doi: 10.15252/embr.201439363

Sekiba, K., Otsuka, M., Ohno, M., Yamagami, M., Kishikawa, T., Suzuki, T., et al. (2018). Hepatitis B virus pathogenesis: Fresh insights into hepatitis B virus RNA. World J. Gastroenterol. 24 (21), 2261-2268. doi: 10.3748/wjg.v24. i21.2261

Shahjin, F., Chand, S., and Yelamanchili, S. V. (2020). Extracellular vesicles as drug delivery vehicles to the central nervous system. J. Neuroimmune Pharmacol. 15 (3), 443-458. doi: 10.1007/s11481-019-09875-w

Shrivastava, S., Petrone, J., Steele, R., Lauer, G. M., Di Bisceglie, A. M., and Ray, R. B. (2013). Up-regulation of circulating miR-20a is correlated with hepatitis C virus-mediated liver disease progression. Hepatology 58 (3), 863-871. doi: 10.1002/hep. 26296

Simon-Santamaria, J., Malovic, I., Warren, A., Oteiza, A., Le Couteur, D., Smedsrød, B., et al. (2010). Age-related changes in scavenger receptormediated endocytosis in rat liver sinusoidal endothelial cells. J. Gerontol. Ser. A. Biol. Sci. Med. Sci. 65 (9), 951-960. doi: 10.1093/gerona/glq108

Soekmadji, C., Russell, P. J., and Nelson, C. C. (2013). Exosomes in prostate cancer: putting together the pieces of a puzzle. Cancers 5 (4), 1522-1544. doi: $10.3390 /$ cancers 5041522

Soekmadji, C., Riches, J. D., Russell, P. J., Ruelcke, J. E., McPherson, S., Wang, C., et al. (2017). Modulation of paracrine signaling by CD9 positive small extracellular vesicles mediates cellular growth of androgen deprived prostate cancer. Oncotarget 8 (32), 52237-52255. doi: 10.18632/oncotarget.11111

Soekmadji, C., Li, B., Huang, Y., Wang, H., An, T., Liu, C., et al. (2020). The future of extracellular vesicles as theranostics - an ISEV meeting report. J. Extracellular Vesicles 9 (1):1809766. doi: 10.1080/20013078.2020.1809766

Soguero, C., Joo, M., Chianese-Bullock, K. A., Nguyen, D. T., Tung, K., and Hahn, Y. S. (2002). Hepatitis C virus core protein leads to immune suppression and liver damage in a transgenic murine model. J. Virol. 76 (18), 9345-9354. doi: $10.1128 /$ jvi.76.18.9345-9354.2002

Sohn, W., Kim, J., Kang, S. H., Yang, S. R., Cho, J.-Y., Cho, H. C., et al. (2015). Serum exosomal microRNAs as novel biomarkers for hepatocellular carcinoma. Exp. Mol. Med. 47 (9), e184-e184. doi: 10.1038/emm.2015.68

Spoden, G., Freitag, K., Husmann, M., Boller, K., Sapp, M., Lambert, C., et al. (2008). Clathrin- and caveolin-independent entry of human papillomavirus type 16-involvement of tetraspanin-enriched microdomains (TEMs). PloS One 3 (10), e3313. doi: 10.1371/journal.pone.0003313

Stieler, J. T., and Prange, R. (2014). Involvement of ESCRT-II in hepatitis B virus morphogenesis. PloS One 9 (3), e91279. doi: 10.1371/journal.pone.0091279

Strickland, M., Ehrlich, L. S., Watanabe, S., Khan, M., Strub, M. P., Luan, C. H., et al. (2017). Tsg101 chaperone function revealed by HIV-1 assembly inhibitors. Nat. Commun. 8 (1), 1391. doi: 10.1038/s41467-017-01426-2

Sukriti, S., Choudhary, M. C., Maras, J. S., Sharma, S., Thangariyal, S., Singh, A., et al. (2019). Extracellular vesicles from hepatitis B patients serve as reservoir of hepatitis B virus DNA. J. Viral Hepatitis 26 (1), 211-214. doi: 10.1111/ jvh.12995

Sumida, Y., Nakajima, A., and Itoh, Y. (2014). Limitations of liver biopsy and noninvasive diagnostic tests for the diagnosis of nonalcoholic fatty liver disease/ nonalcoholic steatohepatitis. World J. Gastroenterol. 20 (2), 475-485. doi: 10.3748/wjg.v20.i2.475

Sung, W. K., Zheng, H., Li, S., Chen, R., Liu, X., Li, Y., et al. (2012). Genome-wide survey of recurrent $\mathrm{HBV}$ integration in hepatocellular carcinoma. Nat. Genet. 44 (7), 765-769. doi: 10.1038/ng.2295
Sung, S., Kim, J., and Jung, Y. (2018). Liver-Derived Exosomes and Their Implications in Liver Pathobiology. Int. J. Mol. Sci. 19 (12), 3715. doi: $10.3390 /$ ijms 19123715

Szabo, G., and Dolganiuc, A. (2008). Hepatitis C and innate immunity: recent advances. Clinics Liver Dis. 12 (3), 675. doi: 10.1016/j.cld.2008.03.003

Takahashi, K., Yan, I. K., Kogure, T., Haga, H., and Patel, T. (2014). Extracellular vesicle-mediated transfer of long non-coding RNA ROR modulates chemosensitivity in human hepatocellular cancer. FEBS Open Bio 4, 458467. doi: 10.1016/j.fob.2014.04.007

Tanaka, Y., Kamohara, H., Kinoshita, K., Kurashige, J., Ishimoto, T., Iwatsuki, M., et al. (2013). Clinical impact of serum exosomal microRNA-21 as a clinical biomarker in human esophageal squamous cell carcinoma. Cancer 119 (6), 1159-1167. doi: 10.1002/cncr.27895

Tang, K., Zhang, Y., Zhang, H., Xu, P., Liu, J., Ma, J., et al. (2012). Delivery of chemotherapeutic drugs in tumour cell-derived microparticles. Nat. Commun. 3, 1282. doi: $10.1038 /$ ncomms 2282

Tang, J., Wu, Z.-Y., Dai, R.-J., Ma, J., and Gong, G.-Z. (2018). Hepatitis B viruspersistent infection and innate immunity defect: Cell-related or virus-related? World J. Clin. cases 6 (9), 233-241. doi: 10.12998/wjcc.v6.i9.233

Théry, C., Witwer, K. W., Aikawa, E., Alcaraz, M. J., Anderson, J. D., Andriantsitohaina, R., et al. (2018). Minimal information for studies of extracellular vesicles 2018 (MISEV2018): a position statement of the International Society for Extracellular Vesicles and update of the MISEV2014 guidelines. J. Extracellular Vesicles 7 (1), 1535750. doi: 10.1080/ 20013078.2018.1535750

Tian, Y., Li, S., Song, J., Ji, T., Zhu, M., Anderson, G. J., et al. (2014). A doxorubicin delivery platform using engineered natural membrane vesicle exosomes for targeted tumor therapy. Biomaterials 35 (7), 2383-2390. doi: 10.1016/ j.biomaterials.2013.11.083

Tirnitz-Parker, J. E., Viebahn, C. S., Jakubowski, A., Klopcic, B. R., Olynyk, J. K., Yeoh, G. C., et al. (2010). Tumor necrosis factor-like weak inducer of apoptosis is a mitogen for liver progenitor cells. Hepatology 52 (1), 291-302. doi: 10.1002/ hep. 23663

Tirnitz-Parker, J. E. E., Olynyk, J. K., and Ramm, G. A. (2014). Role of TWEAK in coregulating liver progenitor cell and fibrogenic responses. Hepatology 59 (3), 1198-1201. doi: $10.1002 /$ hep. 26701

Tong, S., and Li, J. (2014). Identification of NTCP as an HBV receptor: the beginning of the end or the end of the beginning? Gastroenterology 146 (4), 902-905. doi: 10.1053/j.gastro.2014.02.024

Toshikuni, N., Izumi, A., Nishino, K., Inada, N., Sakanoue, R., Yamato, R., et al. (2009). Comparison of outcomes between patients with alcoholic cirrhosis and those with hepatitis C virus-related cirrhosis. J. Gastroenterol. Hepatol. 24 (7), 1276-1283. doi: 10.1111/j.1440-1746.2009.05851.x

Trajkovic, K., Hsu, C., Chiantia, S., Rajendran, L., Wenzel, D., Wieland, F., et al. (2008). Ceramide triggers budding of exosome vesicles into multivesicular endosomes. Science 319 (5867), 1244-1247. doi: 10.1126/science.1153124

Trefts, E., Gannon, M., and Wasserman, D. H. (2017). The liver. Curr. Biol. 27 (21), R1147-R1151. doi: 10.1016/j.cub.2017.09.019

Trepo, C., Chan, H. L., and Lok, A. (2014). Hepatitis B virus infection. Lancet 384 (9959), 2053-2063. doi: 10.1016/s0140-6736(14)60220-8

Tsuchiya, N., Sawada, Y., Endo, I., Saito, K., Uemura, Y., and Nakatsura, T. (2015). Biomarkers for the early diagnosis of hepatocellular carcinoma. World $J$. Gastroenterol. 21 (37), 10573-10583. doi: 10.3748/wjg.v21.i37.10573

Tutrone, R., Donovan, M. J., Torkler, P., Tadigotla, V., McLain, T., Noerholm, M., et al. (2020). Clinical utility of the exosome based ExoDx Prostate(IntelliScore) EPI test in men presenting for initial biopsy with a PSA 2-10 ng/mL. Prostate Cancer Prostatic Dis. doi: 10.1038/s41391-020-0237-z

Varnholt, H., Drebber, U., Schulze, F., Wedemeyer, I., Schirmacher, P., Dienes, H. P., et al. (2008). MicroRNA gene expression profile of hepatitis C virusassociated hepatocellular carcinoma. Hepatology 47 (4), 1223-1232. doi: 10.1002/hep.22158

Vekemans, K., and Braet, F. (2005). Structural and functional aspects of the liver and liver sinusoidal cells in relation to colon carcinoma metastasis. World J. Gastroenterol. 11 (33), 5095-5102. doi: 10.3748/wjg.v11.i33.5095

Viebahn, C. S., Benseler, V., Holz, L. E., Elsegood, C. L., Vo, M., Bertolino, P., et al. (2010). Invading macrophages play a major role in the liver progenitor cell response to chronic liver injury. J. Hepatol. 53 (3), 500-507. doi: 10.1016/ j.jhep.2010.04.010 
Wang, H., Hou, L., Li, A., Duan, Y., Gao, H., and Song, X. (2014). Expression of serum exosomal microRNA-21 in human hepatocellular carcinoma. BioMed. Res. Int. 2014, 864894-864894. doi: 10.1155/2014/864894

Wang, H., Lu, Z., and Zhao, X. (2019). Tumorigenesis, diagnosis, and therapeutic potential of exosomes in liver cancer. J. Hematol. Oncol. 12 (1), 133. doi: 10.1186/s13045-019-0806-6

Wedemeyer, H., He, X. S., Nascimbeni, M., Davis, A. R., Greenberg, H. B., Hoofnagle, J. H., et al. (2002). Impaired effector function of hepatitis C virus-specific CD8+ $\mathrm{T}$ cells in chronic hepatitis $\mathrm{C}$ virus infection. J. Immunol. 169 (6), 3447-3458. doi: 10.4049/jimmunol.169.6.3447

Weis, A., Marquart, L., Calvopina, D. A., Genz, B., Ramm, G. A., and Skoien, R. (2019). Serum MicroRNAs as Biomarkers in Hepatitis C: Preliminary Evidence of a MicroRNA Panel for the Diagnosis of Hepatocellular Carcinoma. Int. J. Mol. Sci. 20 (4), 864. doi: 10.3390/ijms20040864

Westbrook, R. H., and Dusheiko, G. (2014). Natural history of hepatitis C. J. Hepatol. 61 (1 Suppl), S58-S68. doi: 10.1016/j.jhep.2014.07.012

Whiteside, T. L. (2017). Extracellular vesicles isolation and their biomarker potential: are we ready for testing? Ann. Trans. Med. 5 (3), 54-54. doi: $10.21037 /$ atm.2017.01.62

WHO (2017). Guidelines on Hepatitis B and C Testing (Geneva: World Health Organization).

Wolf, P. (1967). The nature and significance of platelet products in human plasma. Br. J. Haematol. 13 (3), 269-288. doi: 10.1111/j.1365-2141.1967.tb08741.x

Wu, Q., Zhou, L., Lv, D., Zhu, X., and Tang, H. (2019). Exosome-mediated communication in the tumor microenvironment contributes to hepatocellular carcinoma development and progression. J. Hematol. Oncol. 12 (1), 53. doi: 10.1186/s13045-019-0739-0
Yamada, E., Montoya, M., Schuettler, C. G., Hickling, T. P., Tarr, A. W., Vitelli, A., et al. (2005). Analysis of the binding of hepatitis $C$ virus genotype 1a and $1 \mathrm{~b}$ E2 glycoproteins to peripheral blood mononuclear cell subsets. J. Gen. Virol. 86 (Pt 9), 2507-2512. doi: 10.1099/vir.0.81169-0

Yan, H., Zhong, G., Xu, G., He, W., Jing, Z., Gao, Z., et al. (2012). Sodium taurocholate cotransporting polypeptide is a functional receptor for human hepatitis B and D virus. eLife 1, e00049-e00049. doi: 10.7554/eLife.00049

Yang, Y. F., Wang, F., Xiao, J. J., Song, Y., Zhao, Y. Y., Cao, Y., et al. (2014). MiR222 overexpression promotes proliferation of human hepatocellular carcinoma HepG2 cells by downregulating p27. Int. J. Clin. Exp. Med. 7 (4), 893-902.

Yang, Y., Han, Q., Hou, Z., Zhang, C., Tian, Z., and Zhang, J. (2017). Exosomes mediate hepatitis B virus (HBV) transmission and NK-cell dysfunction. Cell. Mol. Immunol. 14 (5), 465-475. doi: 10.1038/cmi.2016.24

Zhang, P., Yeo, J. C., and Lim, C. T. (2019). Advances in technologies for purification and enrichment of extracellular vesicles. SLAS TECHNOL.: Translat. Life Sci. Innovation 24 (5), 477-488. doi: 10.1177/2472630319846877

Conflict of Interest: The authors declare that the research was conducted in the absence of any commercial or financial relationships that could be construed as a potential conflict of interest.

Copyright (C) 2020 Lim, Jeffrey, Ramm and Soekmadji. This is an open-access article distributed under the terms of the Creative Commons Attribution License (CC BY). The use, distribution or reproduction in other forums is permitted, provided the original author(s) and the copyright owner(s) are credited and that the original publication in this journal is cited, in accordance with accepted academic practice. No use, distribution or reproduction is permitted which does not comply with these terms. 